\title{
Is Neoliberalism Still Spreading? The Impact of International Cooperation on Capital Taxation
}

\author{
Lukas Hakelberg and Thomas Rixen \\ Freie Universität Berlin \\ Ihnestr. 22 \\ 14195 Berlin, Germany \\ E.mail: lukas.hakelberg@fu-berlin.de and thomas.rixen@fu-berlin.de
}

Postprint. Please cite as: Hakelberg, L. and T. Rixen (2020). "Is neoliberalism still spreading? The impact of international cooperation on capital taxation." Review of International Political Economy. https://doi.org/10.1080/09692290.2020.1752769

\section{Acknowledgments}

Leo Ahrens, Fulya Apaydin, Frank Bandau, Benjamin Braun, Benjamin Faude, Valeska Gerstung, Leonard Geyer, Matthias vom Hau, Steffen Hurka, Friederike Kelle, Christoph Knill, Simon Linder, Daniel Mertens, Richard Murphy, Sol Picciotto, Nils Redeker, Max Schaub, Yves Steinebach, Alexandros Tokhi, Frank Borge Wietzke, Michael Zürn and other participants at the ECPR General Conference in Oslo 2017, the IBEI Research Seminar and Workshop 'Policy-Making in Hard Times' in Barcelona in 2017, the Conference of the German Political Science Association’s (DVPW) Political Economy Section in Darmstadt 2018, the Tax Justice Network's Annual Conference 2018 in Lima and the Global Governance Colloquium at the Social Science Research Center Berlin (WZB) in May 2019 as well as three anonymous reviewers provided very helpful comments and suggestions. We thank all of them. 


\title{
Is Neoliberalism Still Spreading? The Impact of International Cooperation on Capital Taxation
}

\begin{abstract}
The downward trend in capital taxes since the 1980s has recently reversed for personal capital income. At the same time, it continued for corporate profits. Why have these tax rates diverged after a long period of parallel decline? We argue that the answer lies in different levels of change in the fights against tax evasion and tax avoidance. The fight against evasion by households progressed significantly since 2009, culminating in the multilateral adoption of automatic exchange of information (AEI). In contrast, international efforts against base erosion and profit shifting (BEPS) failed to curb tax avoidance by corporations. We theorize that international cooperation is an intervening variable, countering the negative impact of tax competition on capital taxation by reducing the risk of capital flight. Under such conditions, domestic political pressures in favor of higher capital taxes can unfold. We confirm our argument in a differencein-difference analysis and through additional tests with data for up to 35 OECD countries from 2000-2017. Our central estimate suggests that the average tax rate on dividends in 2017 is 4.5 percentage points higher than it would have been absent international tax cooperation.
\end{abstract}

Key Words: Capital Taxation; Globalization; International Cooperation, Tax Evasion and Avoidance; Automatic Exchange of Taxpayer Information. 


\section{Introduction}

The spread of neoliberal ideas, institutions and policies since the 1980s is a key finding of international and comparative political economy (Simmons et al., 2006; Widmaier, 2016). An important indicator for neoliberal reform has been the downward trend in tax rates imposed on capital. Virtually all countries have cut taxes on capital gains, interest and dividends during the 1990s and 2000s, justifying corresponding reforms with the need to promote private saving and investment and prevent capital flight (Ganghof, 2006; Swank, 2006). But this downward trend has recently reversed. Between 2009 and 2017, member states of the Organisation for Economic Co-operation and Development (OECD) raised net tax rates on dividends at the shareholder level by 4 percentage points on average. ${ }^{1}$ How can we account for this rebound?

We argue that international cooperation, producing increasingly stringent standards for the exchange of information on bank accounts held by non-residents, reduced the risk of capital flight perceived by policymakers, thereby enabling them to raise taxes on capital income. But information exchange does not increase taxes by itself. It curbs the structural constraint of tax competition preventing policymakers from responding to domestic drivers of tax reform. Without corresponding demand, governments will not increase taxes on capital income. In order to isolate the causal effect of international cooperation, we leverage a quasi-natural experiment, exploiting the concomitance of fundamental change in the fight against tax evasion and a resilient status quo in the fight against tax avoidance.

Tax evasion occurs when an individual illegally conceals capital income from the tax office. The crucial prerequisite for this concealment is financial secrecy provided by tax havens. In contrast, tax avoidance occurs when multinational corporations (MNCs) exploit legal accounting practices to shift profits from branches in normal tax countries to branches in tax havens. These shifts are enabled by a principle in international tax law that obliges tax authorities to 
treat subsidiaries of a group as separate entities. Both tax evasion and avoidance rely on international capital mobility and have traditionally served as justifications for tax cuts on capital income and corporate profits (Genschel \& Schwarz, 2011). Accordingly, OECD countries’ corresponding tax rates declined in parallel prior to 2009.

That year, however, governments in the Group of 20 (G20) and the OECD began to reform global standards for administrative assistance in tax matters. In a first step, they updated the OECD’s standard for information exchange upon request and eventually adopted the automatic exchange of information (AEI) on bank accounts held by non-residents (Emmenegger, 2017). Although the process was incremental, the multilateral adoption of AEI in 2014 represents fundamental change, as it provides national tax administrations with regular and comprehensive information on their taxpayers' foreign capital income for the first time. Through its adoption by all traditional tax havens - precipitated by a credible threat of sanctions from the United States (US) - the veil of secrecy, formerly enabling individuals to hide capital income offshore, was lifted (Christensen \& Hearson, 2019).

In contrast, efforts to curb corporate tax avoidance have not yielded similar progress so far. In response to a series of investigative reports uncovering tax avoidance by well-known MNCs, the G20 mandated the OECD in 2012 to launch an initiative against base erosion and profit shifting (BEPS). The project's ambition was to realign corporate taxation with value creation. But analysts agree that its outcomes fall short of this objective, essentially preserving the status quo. The BEPS project yielded some incremental change with the introduction of country-bycountry reporting (CbCR) (Seabrooke \& Wigan, 2016). But the separate entity principle, enabling MNCs to shift profits between branches, and the arm's length standard (ALS), providing MNCs with considerable leeway in the pricing of intrafirm transactions when comparable transactions do not exist between unrelated firms, remain in place (Büttner \& Thiemann, 2017; Hakelberg, 2020; Lips, 2019; Picciotto, 2015). 
Whereas the prerequisites for tax evasion have largely been removed, the prerequisites for tax avoidance remain in place. Therefore, policymakers should associate an increase in taxes on corporate profits with a higher risk of capital flight than an increase in taxes on personal capital income. Indeed, following the adoption of multilateral AEI, Pascal Saint-Amans, head of the OECD’s Center for Tax Policy and Administration, argued that 'for the past 30 years we’ve been saying don't try to tax capital more because you'll lose it, you'll lose investment. Well this argument is dead, so it's worth revisiting the whole story' (Creighton, 2016). Following similar reasoning, the German coalition government of CDU and SPD explicitly justifies its current plan to abolish a tax rebate for personal capital income with the establishment of multilateral AEI (CDU et al., 2018, p. 69).

Different levels of change in the fights against tax evasion and avoidance provide us with considerable analytical leverage, because existing theories of domestic tax policymaking expect the determinants of tax increases on capital income and corporate profits to be identical. Among others, the literature links center-left governments, institutional veto players, voters' fairness concerns, and public deficits to higher average effective tax rates on capital (AETRs) (Basinger \& Hallerberg, 2004; Plümper et al., 2009; Swank \& Steinmo, 2002). But since AETRs lump the tax burdens on capital income and corporate profits together, arguments developed in these studies cannot explain divergence between the two tax rates. By comparing the evolution of tax rates imposed on dividend income at the shareholder level to the evolution of tax rates imposed on corporate profits before and after 2009, we can thus isolate the effect of international cooperation from changes at the domestic level.

To this end, we perform a difference-in-differences (DID) analysis, studying the gap between mean tax rates imposed by OECD countries on dividends at the shareholder level (treatment group) and on corporate profits (control group) before and after 2009, the year G20 leaders 
declared the end of banking secrecy (treatment). Controlling for confounders linked to the financial crisis, our results show that both tax types were subject to downward pressure prior to 2009 and confirm a substantial and statistically significant break in trends thereafter. Our central estimate suggests that the average tax rate on dividends in 2017 is 4.5 percentage points higher than it would have been absent international tax cooperation.

These findings are relevant to two politically salient debates in international political economy. First, there is concern about increasing income and wealth inequality in almost all developed countries (Alvaredo et al., 2018). Tax evasion significantly contributes to this trend. By far the largest part of overall evasion is concentrated in the top 1 percent of wealth owners, who evade up to $30 \%$ of what they owe in taxes, compared to around $3 \%$ for the other $99 \%$ (Alstadsæter et al., 2019). So effective international tax enforcement by itself contributes significantly to fighting inequality. Moreover, Saez and Zucman (2019) show that effective prevention of tax evasion increases the optimal tax rate on capital, the rate producing the most efficient allocation of resources. Better tax enforcement thus enables policymakers to increase the progressivity of their tax systems without compromising efficiency. Our study contributes empirical flesh to this theoretical insight. As the degree of tax progressivity is the most important predictor of variation in income distributions (e.g. Atkinson, 2015; Piketty et al., 2018), higher capital taxes will have to be part of any policy package aiming to reduce income inequality. While the focus is often on domestic policies only, we emphasize that effective international cooperation is a necessary precondition for national reforms.

Second, this article informs debate on the populist backlash against globalization. According to standard economic theory, globalization leads to aggregate gains for the nation but losses for some groups and sectors. For economic globalization to be politically stable, national polities will have to compensate these losers. But 'hyperglobalization' - fully unrestricted capital 
mobility and 'behind the border' trade liberalization - puts the nation into a 'golden straightjacket' preventing redistribution in favor of globalization losers. Consequently, a significant part of the populist backlash against elites and liberalism is also directed at globalization itself (Rodrik, 2018). The populist answer usually involves protectionism, which is likely to hurt rather than benefit adversely affected groups.

Therefore, Rodrik argues for a return to ‘sensible globalization', maintaining free trade but leaving nation-states enough policy autonomy to design and implement compensatory policies. We show that taxation is a case in point. It is the most important instrument of domestic redistribution and severely afflicted with the problems of hyperglobalization in the form of harmful tax competition (Rodrik, 2011, pp. 357-360). Rodrik focuses on trade, but a number of policy proposals to regulate harmful tax competition fit into his normative vision of strengthening domestic policy autonomy, including AEI (c.f. Dietsch \& Rixen, 2016; Saez \& Zucman, 2019). We show that this type of cooperation bolsters governments' capacity to tax mobile capital, thereby enabling them to compensate globalization losers. In contradistinction to the populist claim that national sovereignty requires the unilateral withdrawal from international cooperation, we show that effective national tax sovereignty needs more and better cooperation.

We proceed as follows. In the subsequent section, we review the literature and develop our theoretical argument. Section three provides evidence for fundamental change in the fight against tax evasion and the persistence of the status quo in the fight against tax avoidance. In section four, we present our method, data and empirical results, including an illustrative example of tax reform in the United Kingdom (UK). Section five discusses our findings' implications for important debates on increasing income and wealth inequality, the backlash against globalization, and the interaction of material and ideational factors in fostering policy change. 


\section{Tax Competition, Countervailing Pressures and International Cooperation}

\subsection{Capital Taxation in Open Economies}

Neoliberal tax systems feature low rates and uniform structures. The tax burden on capital owners, as reflected in taxes on dividends, interest and top incomes, is small to provide incentives for saving and investment. In contrast, indirect taxes on consumption may be increased to achieve uniformity. The overall aim is a tax system interfering as little as possible with the 'natural' working of the market. This requires neutrality across different economic activities and the design of broad tax bases through the removal of targeted expenditures (Sandford, 1993). Such systems reject the objectives of Keynesian tax policy, including demand stabilization, the promotion of social equity through progressive taxation, and the subordination of private investment to broader societal goals (Bird, 1980; Steinmo, 2003). With tax rates on capital and top incomes steadily falling since the 1980s, neoliberal tax policy has diffused across all OECD countries albeit with some variation (Swank, 2006).

The literature discusses various explanations of capital tax rates that broadly fall into three groups. A first strand focuses on international tax competition. From this perspective, the free movement of capital pressures governments into undercutting each other's taxes to attract investment (Zodrow \& Mieszkowski, 1986). There is abundant empirical evidence for the sensitivity of investment to tax rate differentials and for competitive interactions between governments (Genschel \& Schwarz, 2011; Mooij \& Ederveen, 2008). Indeed, after the United States opened the era of tax competition with the 1986 tax reform act, other countries also cut statutory tax rates on corporate profits and personal capital income and broadened tax base definitions. Hence, competition has been an important driver of the global diffusion of neoliberal tax structures (Swank, 2006).

Skeptics of tax competition have in the past stressed that tax revenues and effective tax rates did not fall significantly (Basinger \& Hallerberg, 2004; Garrett \& Mitchell, 2001). Beyond the 
fact that recent studies question this finding (Dyreng et al., 2017), there are three reasons why it does not invalidate the claim that tax competition is a potent force. First, since the return on investment increased significantly during the observed time period, governments should have collected more rather than constant tax revenue from capital income and corporate profits (Clausing, 2007). Second, the tax base, which is the denominator in effective tax rate indicators, is underestimated because of tax evasion and avoidance, i.e. tax base hidden offshore. Thus the indicator remains constant, if the numerator also falls (or increases if the numerator is constant). (Mooij \& Ederveen, 2008, pp. 684-685). Third, the distributive consequences of tax cuts on corporate profits and personal capital income match a tax competition account: governments have shifted the tax burden from internationally mobile capital to immobile factors (Egger et al., 2019).

A second strand of the literature emphasizes countervailing pressures moderating the effect of international tax competition. Center-left parties, for instance, hesitate longer than conservative parties to cut taxes on capital (e.g. Cusack, 1999). Other accounts suggest that the median voter's fairness concerns provide a backstop to regressive tax reform (Plümper et al., 2009). In particular, unequal treatment of lower and upper-class citizens during wartime or financial crises may fuel popular demand for compensation, including higher taxes on capital owners (Limberg, 2018; Scheve \& Stasavage, 2016). Next to political preferences, many studies focus on institutions. Countries with more demanding veto player constellations and consensus democracies are slow in cutting taxes on capital (Basinger \& Hallerberg, 2004). Likewise, countries with strong corporatism and coordinated market economies maintain higher taxes on capital despite tax competition (Swank \& Steinmo, 2002).

Moreover, capital taxation may also react to functional and ideational pressures. Budget constraints reflected in public deficits or sovereign bond yields could lead to tax increases (Lierse \& Seelkopf, 2016). Alternatively, tax hikes may be caused by new policy ideas and 
learning. Just as neoliberal ideas have justified tax cuts on capital since the 1980s (Steinmo, 2003), the recent reversal could result from the emergence of a new inclusive growth paradigm (Brys et al., 2016; International Monetary Fund, 2014). After all, the notion that higher taxes on capital do not only increase fairness but also entail efficiency gains has received some attention in recent debates (Chetty \& Saez, 2010; Piketty et al., 2014). In sum, these contributions show that some countries maintain higher taxes on mobile capital than others despite competitive pressure. While tax competition dominates countervailing forces, they account for interesting variation in the extent to which countries cut tax rates.

Third, international cooperation could moderate the impact of tax competition. This possibility is discussed in a literature strand, assessing the effectiveness of different types of information exchange. Corresponding studies found that information exchange on request, does not deter tax evasion because of restrictive conditions imposed on administrations demanding account data (Johannesen \& Zucman, 2014). Analysts also identified loopholes in the first version of the EU's savings tax directive (STD), which introduced AEI on interest payments but not on distributions of dividends or capital gains (Rixen \& Schwarz, 2012). In contrast, recent studies show that comprehensive AEI - either embedded in the Obama administration's Foreign Account Tax Compliance Act (FATCA) or the OECD’s common reporting standard (CRS) - curbs tax evasion by households with foreign accounts. Since their adoption, formerly secretive tax havens have lost a substantial share of their foreign deposit base (Ahrens \& Bothner, 2019; Hakelberg \& Schaub, 2018), and saw important declines in the number of registered shell companies (Omartian, 2017).

\subsection{International Cooperation as Enabling Factor}

The approaches discussed above contribute important insights into the determinants of capital taxation in developed economies. But none of them can on its own explain the increase in taxes on dividends at the shareholder level and the continued decline in taxes on corporate profits 
since 2009. Previous research shows that portfolio investment and deposits are at least as sensitive to tax rate differentials as foreign direct investment. Hence, theories of tax competition expect a continued decline in both types of taxes (Genschel \& Schwarz, 2011, pp. 348-350). Similarly, theories of countervailing pressures point to domestic factors that preserve a relatively high level of capital taxation under conditions of tax competition. But their hypothesized effect is usually applied to AETRs, which lump taxes on corporate profits and personal capital income together (e.g. Basinger \& Hallerberg, 2004, p. 268; Plümper et al., 2009, p. 773; Swank \& Steinmo, 2002, p. 646). Finally, international tax cooperation may curb downward pressure on tax rates, but none of the cooperative measures implemented so far imposes minimum tax rates on national governments.

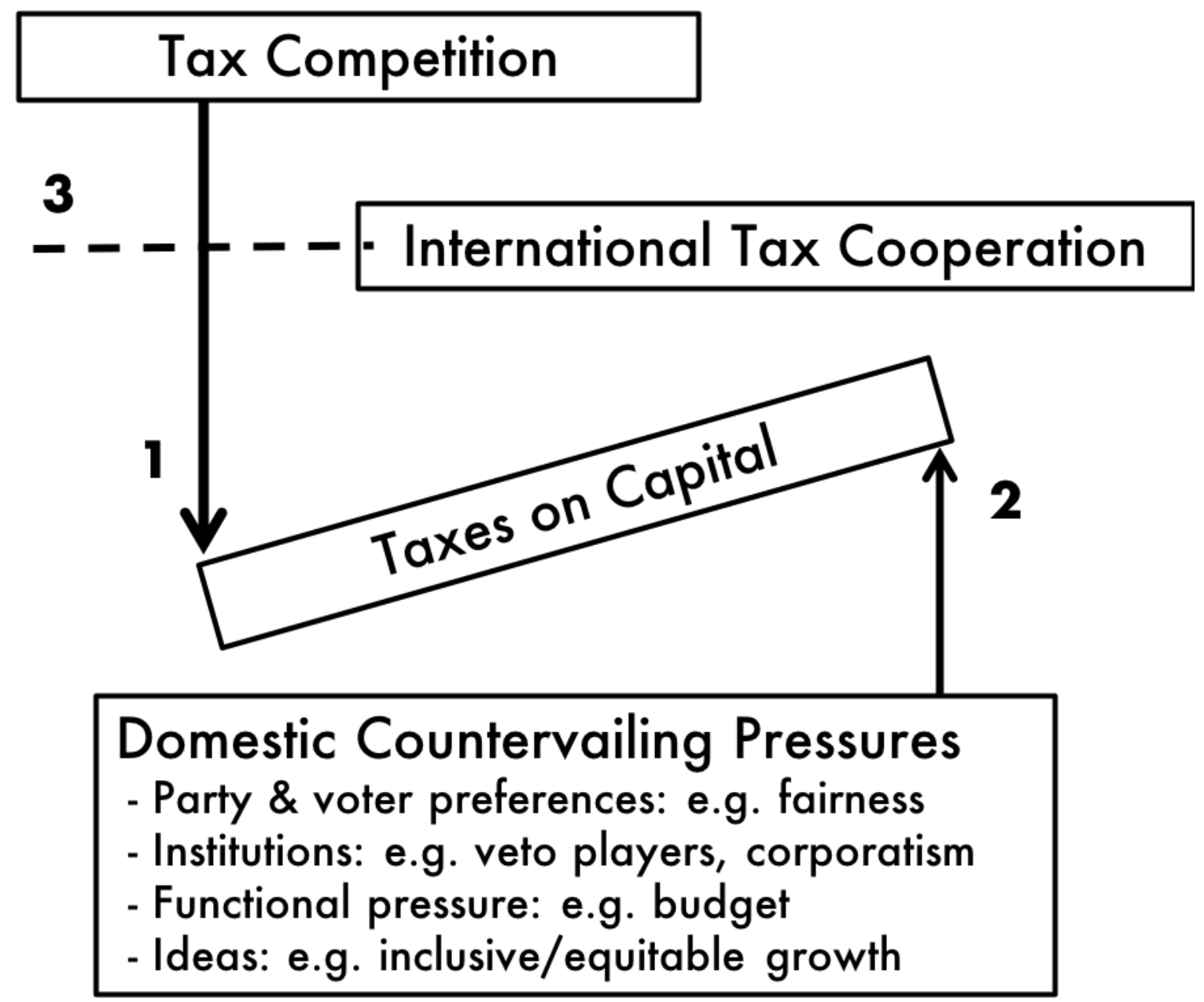

Figure 1: International Cooperation as Intervening Variable 
We argue that combining the three approaches enables us to explain the observed divergence in mean tax rates on corporate profits and dividends. Our explanatory framework is summarized in Figure 1. Tax competition is one determinant of tax rates on capital and its effect is negative (arrow 1). Domestic countervailing pressures provide a counterweight (arrow 2). International cooperation comes in as an intervening variable (line 3). When it curbs tax competition, domestic countervailing pressures unfold their effect and raise tax rates on capital. ${ }^{2}$ Against this background, we formulate the following hypothesis: The expectation of effective cooperation against tax evasion has since 2009 enabled OECD governments to raise taxes on dividends at the shareholder level.

Our conjecture has four empirical implications. Theories of tax competition expect countries to undercut each other's tax rates to attract investment. Hence, (1) the mean tax rates on dividends and corporate profits should follow a common downward trend prior to the G20's endorsement of financial transparency in 2009. Once the G20 declaration causes policymakers to expect strong anti-evasion measures, (2) the mean tax rate on dividends should increase, whereas the mean tax rate on corporate profits should continue to decline. Moreover, tax competition should also reduce the variation of tax rates by forcing otherwise heterogeneous countries to converge towards a similar tax level (Holzinger et al., 2008, p. 566; Simmons et al., 2006, p. 784). Hence, (3) the variation in tax rates on dividends and on corporate profits across countries should decline until 2009. From that year, however, (4) the variation in tax rates on dividends should increase again, whereas variation in tax rates on corporate profits should continue to decline.

\section{The Divergent Trajectories of International Tax Cooperation}

Before we test these implications below, this section demonstrates that international cooperation produced fundamental change in the fight against tax evasion, but not in the fight against 
tax avoidance. Tax evasion occurs when individuals underreport income or wealth held in offshore accounts in their income tax statement. Its decisive prerequisite is financial secrecy provided by tax havens through banking secrecy laws, anonymous shell companies or trusts (Harrington, 2016; Palan et al., 2010). In contrast, tax avoidance occurs when MNCs exploit fundamental principles of international tax law to shift profits from normal tax countries to tax havens.

\subsection{Fundamental Change in the Fight against Tax Evasion}

Households are legally obliged to report their worldwide income on their income tax statement. Because of financial secrecy, however, tax authorities traditionally had a hard time detecting underreporting. Before the 2000s, they could merely lodge requests for account information, if they had signed a bilateral tax treaty (BTT) with the country hosting the account. Requests presupposed prior evidence of tax evasion by particular individuals and depended on the domestic availability of requested information. In practice, tax haven governments usually argued that secrecy provisions prevented them from accessing the requested data (Rixen, 2008, p. 75 ff.). The low risk of detection made tax evasion highly popular among wealthy elites in OECD countries. According to the most conservative estimate, 8 percent of global financial wealth was held unrecorded in tax havens between 2001 and 2008 (Zucman, 2013, p. 1323).

Tax evasion causes immediate revenue losses and exacerbates income inequality by reducing the taxable income of the wealthiest households (Alstadsæter et al., 2019). But it also creates indirect losses by pressuring residence countries into tax competition. Absent meaningful tax cooperation, most OECD countries chose to cut taxes on capital income to prevent capital flight to tax havens (Ganghof, 2006; Genschel \& Schwarz, 2013). Peer Steinbrück, the former German minister of finance, summarized the general logic when introducing a special tax rebate for personal capital income in 2006. From his perspective, '25\% of X was still better than $42 \%$ 
of nothing' (Handelsblatt, 2006). With a lower premium on tax evasion, he hoped, fewer taxpayers would risk charges for underreporting returns to their foreign accounts.

Since information exchange upon request did not deter tax evasion, tax authorities in the United States and Europe began to experiment with AEI mechanisms. In 2000, the Clinton Treasury introduced the Qualified Intermediary (QI) program, obliging foreign banks to automatically report US-source income earned by US clients to the Internal Revenue Service (IRS) (IRS, 2000). In 2003, EU finance ministers adopted the Savings Tax Directive (STD). The directive introduced AEI on interest payments among member states and was extended to Liechtenstein and Switzerland through analogous savings agreements (Rixen \& Schwarz, 2012). Yet, both instruments suffered from narrow income definitions and did not oblige banks to look through legal entities. By hiding clients from the US and EU behind trusts or shell companies and divesting their portfolios of US assets or debt securities, foreign banks could avoid reporting them. Accordingly, both measures failed to precipitate repatriations of hidden wealth (Government Accountability Office, 2007; Johannesen, 2014).

But the circumvention strategies eventually backfired. From 2007, whistleblowers provided US and European tax authorities with information on how Liechtenstein Global Trust (LGT) and Union Bank of Switzerland (UBS) avoided the reporting of foreign clients (Balzli et al., 2008; Levin \& Coleman, 2008). In response to the ensuing scandals, France and Germany put the extension of the STD's AEI mechanism to all types of capital income on the agenda of the Council of the EU in March 2008 and lobbied for progress on financial transparency at the G20’s first crisis meeting in November of the same year (Hakelberg, 2020, p. 94 ff.). In the United States, senator Carl Levin, staged a hearing on the circumvention of the QI program by LGT and UBS in July 2008 and the Department of Justice (DoJ) threatened to indict UBS and other Swiss banks for conspiring to defraud the United States (Emmenegger, 2017, p. 30 ff.). 
Eventually, Barack Obama pledged to lead the world to new standards for information exchange during the presidential campaign (Montgomery \& Wilson 2009).

Against this background, G20 leaders declared in April 2009 that 'the era of banking secrecy was over.' Initially, they announced sanctions against countries failing to apply a 2005 revision of the OECD’s upon request standard in their tax treaties (G20 Leaders, 2009; OECD, 2009). The revision ensured that administrative assistance could no longer be refused because requested information was not collected domestically (OECD, 2017, p. 46). While the new standard allowed the United States to reduce tax evasion (Hanlon et al., 2015; Johannesen et al., 2018), the remaining OECD countries were less successful. Because tax havens merely needed 12 information exchange treaties (either updated BTTs or special tax information exchange agreements) to avoid being blacklisted, committed tax evaders transferred formal account ownership to entities in jurisdictions that did not have a corresponding agreement with their home country (Johannesen \& Zucman, 2014).

Since the EU and US had announced to make their AEI regimes more comprehensive in response to the LGT and UBS scandals, however, policymakers expected that this move by the G20 was merely the beginning. According to Jean-Claude Juncker, then prime minister of Luxembourg, multilateral AEI loomed on the horizon by mid-2009. ${ }^{3}$ A report on British offshore centers for the UK's chancellor of the exchequer concluded in October 2009 that 'the trend for greater transparency is likely to result in pressure to move to a system of automatic exchange of information' (Foot, 2009, p. 10). Like tax evaders, who react to transparency measures upon their announcement rather than their entering into force (Ahrens \& Bothner, 2019; Huizinga \& Nicodème, 2004), finance ministers anticipated that the G20’s call for financial transparency would culminate in the adoption of multilateral AEI.

In fact, the US Treasury had begun to develop FATCA in early 2009 to close loopholes in the QI program revealed by the LGT and UBS scandals. The act, which was eventually adopted 
by congress in March 2010, imposes a 30\% withholding tax on payments from the United States to foreign financial institutions (FFIs) refusing to automatically report their US clients to the IRS. FFIs thus had to lobby their home governments for the abolition of secrecy provisions. From 2012, parliaments around the world changed domestic legislation before ratifying intergovernmental agreements (IGAs) on FATCA implementation with the US Treasury. These reforms and the commitment to AEI in their IGAs invalidated the legal arguments tax havens had used to refuse the dissemination of account information. Against this background, the G20 tasked the OECD to develop a common reporting standard (CRS) based on FATCA (Hakelberg, 2016, pp. 134-135).

In October 2014, 51 countries adopted the CRS by multilateral agreement (MCAA) and a further 58 have joined since, including all countries formerly notorious for their financial secrecy (OECD, 2018). In parallel, Austria and Luxembourg's signature of IGAs with the United States enabled the EU to break their opposition to an extension of the STD's AEI mechanism to all types of capital income and all EU member states (Hakelberg, 2015). The announcement of AEI by key actors substantially reduced the value of foreign deposits in tax havens relative to non-havens (Ahrens \& Bothner, 2019; Hakelberg \& Schaub, 2018). Large residence countries have since earned billions in back taxes and fines (IRS, 2016), and despite the US government's refusal to fully reciprocate the AEI, OECD countries had on average covered $83 \%$ of their investment networks with AEI relationships in 2017, reflecting an unprecedented level of financial transparency (cf. Jansky et al., 2018).

\subsection{A Resilient Status Quo in the Fight against Tax Avoidance}

Whereas OECD countries made financial transparency the norm and secrecy the exception, their parallel effort to curb tax avoidance left the separate entity principle and ALS in place. According to the former, the branch of an MNC is taxable by the state in which it is permanently established (OECD, 2017, pp. 33-34). Since the activities of MNCs are spread across branches 
in many countries, however, the headquarter can exploit its control over the group's integrated wealth chains to channel taxable income to holding companies in tax havens (Seabrooke \& Wigan, 2017). Because of the ALS, a widespread strategy to this effect is the manipulation of transfer prices. An MNC’s tax haven holding may, for instance, overcharge its sister subsidiaries for the use of the group's IP, thereby siphoning off their local profits. Tax authorities can only revalue this transaction, if they find a similar transaction between independent firms. But unique IP often entails a lack of comparables, precluding post-hoc corrections of transfer prices (Picciotto, 1992, 2015).

Accordingly, MNCs avoid tax payments of between $\$ 500$ and 650 billion every year (Cobham \& Janský, 2018; Crivelli et al., 2016). Again, direct losses are exacerbated by competitive pressure. To guard themselves against excessive outflows of taxable profits, OECD countries have on average cut the statutory corporate tax rate, which is the decisive marker for competitiveness (Devereux et al., 2008), by 50\% since 1983 (see figure 2 below). From 2009, however, investigative reports uncovered how US MNCs exploited the separate entity principle and ALS to avoid taxes in the EU (e.g. Bergin, 2012; Murphy, 2009). Public indignation motivated the German and British governments to also put corporate tax avoidance on the G20's agenda. ${ }^{4}$ The Obama administration welcomed their initiative, as it had pledged - but hitherto failed - to end the indefinite deferral of tax payments on foreign income US MNCs were amassing in tax havens (Grinberg, 2015, p. 1171). Hence, the G20 mandated the OECD to develop the BEPS project and deliver countermeasures to tax avoidance by 2015 (G20 Leaders, 2013).

From the outset, the OECD made clear that because of the tight deadline and 'the practical difficulties associated with agreeing to [...] a new system,' solutions to BEPS should be found within the bounds of existing principles (OECD, 2013, p. 20). Rather than taxing MNCs as unitary entities and apportioning the revenue among governments based on a certain formula, the OECD’s most radical proposals included special measures, CbCR and a lower permanent 
establishment threshold. Special measures were supposed to enable tax authorities to recharacterize or disregard intrafirm transactions involving tax havens or hard-to-value intangibles (HTVI) (OECD, 2014a, pp. 41-44). CbCR should oblige MNCs to disclose tax payments, profits, and activities on a per country basis, so that tax authorities and civil society could easily identify mismatches (OECD, 2014b, p. 15). A lower PE threshold was supposed to prevent ecommerce platforms from avoiding a taxable presence in countries in which they merely distribute goods to customers (OECD, 2014c, pp. 15-17).

Large EU member states were in favor of these proposals as they promised to extend the reach of their tax authorities over a digital economy dominated by US MNCs (Fehling, 2014, pp. 639-640). Moreover, EU countries wanted to secure support for OECD standards from China and other emerging economies in the G20 (Kreienbaum, 2014, p. 637), which were invited to the negotiating table but remained skeptical of the ALS (Hearson \& Prichard, 2018). In contrast, the Obama administration opposed the proposals. In its view, tax avoidance in the EU did not pose a problem as long as resulting profits were included in the US headquarters' tax statement. Hence, US negotiators tried to focus debate on controlled-foreign-company (CFC) rules, which allow tax authorities to add passive income amassed in tax havens to the headquarters' tax base (Grinberg, 2015, p. 1171). Transatlantic conflict crystallized on the question, who could claim taxing rights over the cash piles of US MNCs in tax havens.

Unlike it had done with FATCA, however, the Obama administration could not enforce its regulatory model because US business organized opposition to stronger CFC rules in congress. Therefore, US negotiators ended up defending the status quo. From their perspective, a minimal foreign tax burden for US MNCs was still better than surrendering tax base to European governments (Herzfeld, 2015). At the insistence of US negotiators, the possibility to disregard controlled transactions with tax havens disappeared from the BEPS project's final recommendations and ex-post adjustments of transfer prices for HTVI were limited to a five-year period 
after an asset's commercialization (Finley, 2016). Although CbCR survived, US negotiators prevented the publication of reports and ensured that MNCs do not have to report crucial information on intrafirm royalty, dividend and interest payments (Stewart, 2014). Finally, the expanded PE definition was not included in the MTC after the US representative threatened to file a reservation (Martin, 2015). Parties to an existing BTT now merely have the option to adopt the broader definition if both sides agree (OECD, 2015, p. 14). As the BEPS project's final recommendations essentially preserve the status quo, the latest estimates of tax avoidance show no sign of abatement until the end of our observation period in 2017 (Cobham \& Janský, 2019; Tørsløv et al., 2018).

\section{The Impact of International Tax Cooperation on National Tax Policy}

OECD governments benefit from fundamental change in the fight against tax evasion while the fight against tax avoidance has not yet overcome the status quo. We now test in three steps whether this divergence affects national tax policy. To test empirical implications 1 and 2, we perform a DID analysis comparing tax rates imposed on dividends at the shareholder level and corporate profits before and after G20 leaders declared the end of banking secrecy in 2009 (section 4.1). In section 4.2, we test whether our proposed causal mechanism, reduced competitive pressure, is also reflected in rebounding variation of tax rates on dividends as opposed to tax rates on corporate profits (empirical implications 3 and 4). In section 4.3, we illustrate the causal mechanism with a case study of a 2009 tax reform in the UK that increased the tax rate on dividends at the shareholder level from 25 to $36 \%$.

\subsection{Comparing (Mean) Tax Rates: A DID Analysis}

Our DID model compares the tax rates (outcome) on dividends at the personal level (treatment group) and on corporate profits (control group) imposed by OECD governments before and after G20 leaders declared the end of banking secrecy in 2009 (treatment). Taxes on corporate 
profits should be the perfect control group for our purposes because conventional explanations of capital taxation expect them to coevolve with taxes on dividends (see section 2). At the same time, taxes on corporate profits should be unaffected by the G20's declaration, since corporate tax avoidance - as opposed to tax evasion by households with foreign accounts - does not rely on financial secrecy. As the risk of profit shifting persists, the competitive pressure on corporate tax rates also persists.

Tax rate data comes from the OECD’s tax database (OECD, 2019). We obtain data on corporation taxes from the database's table II.1, where we use the indicator 'combined corporate income tax rate,' which compiles member states' 'combined central and sub-central (statutory) corporate income tax rate given by the central government rate (less deductions for sub-national taxes) plus the sub-central rate.' Data on dividend taxes comes from the database's table II.4, where we use the item 'net personal tax,' which 'shows the net top statutory rate to be paid at the shareholder level, taking account of all types of reliefs and gross-up provisions at the shareholder level.' We focus on dividend taxation because no comparable time series is available for taxes on capital gains and interest. But a recent OECD study comparing data for 2012 and 2016 reveals similar trends for these income types (Harding \& Marten, 2018). We also ignore foreign withholding taxes because all OECD countries either have a credit or an exemption system in place, neutralizing their impact on an investor's domestic tax burden (Rixen, 2008, p. 210).

Figure 2a exhibits a common downward trend in the mean tax rates on dividends and corporate profits between 2000 and 2009. Whereas the mean corporate tax rate fell from 32.5 to $25.5 \%$, the mean tax rate on dividends declined from 23.8 to $19.6 \%$. The latter's small rebound between 2004 and 2006 results from the abolition of full imputation in Finland and Norway. Finland increased its net personal tax on dividends from 0 to 16 percent in 2005 after the European Court of Justice had found its imputation system, which only applied to Finnish citizens, in violation of the principle of non-discrimination. Norway raised its tax from 0 to 28 percent 
in 2006 to prevent active owners of closely held corporations from avoiding taxes by paying themselves dividends instead of wages (Ganghof, 2006, pp. 77-111). ${ }^{5}$ These are the largest year to year increases in the dataset. Hence, the downward trend for the mean tax rate on dividends aligns even better with the trend for the mean rate on corporate profits when we drop Finland and Norway (figure 2b). 

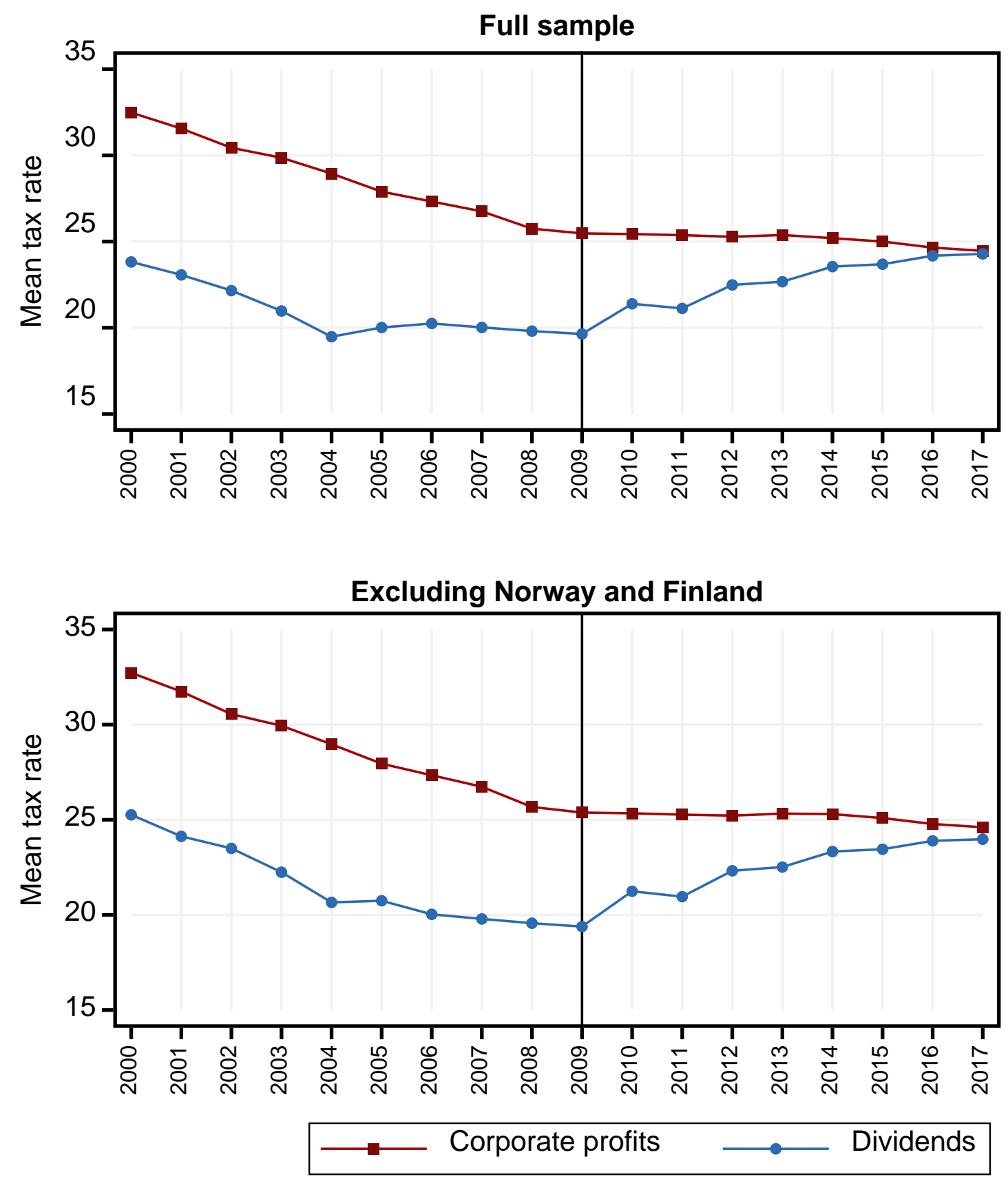

Figure 2: Average Tax Rates Imposed on Dividends and Corporate Profits in OECD Countries (\%, taxable income)

Figure 2 suggests that the common trend assumption underpinning the DID method holds for the pretreatment period. From 2009, however, we observe a substantial divergence in the trends of the mean tax rates. Whereas the rate imposed on corporate profits remains unchanged until 2013 and then declines to 24.4\% by 2017, the rate on dividends increases by almost 5 
percentage points to $24.3 \%$ in the same year. Given the previous parallel trends, this divergence could be due to a treatment in 2009 that only affected tax rates on dividends. To test this proposition, we begin by estimating the following regression:

$$
\text { (1) } \text { taxrate }_{d c t}=\gamma_{c}+\lambda_{t}+\beta_{1} \text { dividend }_{c t}+\beta_{2} X_{c t}+\epsilon_{c t}
$$

Whereby taxrate $_{d c t}$ is the taxrate on dividends or corporate profits (indicated by subscript d) in country $c$ at time $t . \gamma_{c}$ are fixed effects for the different countries, $\lambda_{t}$ are indicators for the year of observation, dividend ${ }_{c t}$ is a dummy that takes the value of 1 for all dividend rate observations in 2009 and all subsequent years and the value of 0 otherwise. $\epsilon_{c t}$ is an error term. To correct for potential year-to-year serial correlation in the values of the dependent variable within countries, we bootstrap standard errors in all calculations (1000 repetitions), blocking at the country level. This is the recommended procedure for samples with a large number of clusters (Bertrand et al., 2004, pp. 265-266). Excluding Norway and Finland we have 33 countries in our regressions, each contributing two time series, i.e. 66 clusters. $X$ is a placeholder for the covariates we introduce. While the DID method already controls for all factors expected to affect taxes on dividends and corporate profits in the same way (as long as the common trend assumption holds), we have to control for confounders that could have a differential effect on dividend and corporate profit tax rates.

Three factors are relevant in this respect. The financial crisis of 2008 affected tax policy through three partially contradicting channels. By creating the need for fiscal stimulus, it put downward pressure on all taxes depressing corporate investment. But the crisis also deepened public deficits by forcing governments to bail out failing banks and created demand for compensatory fairness from indignant voters (Limberg, 2018). Both factors put upward pressure on corporate and personal income taxes among others. In trying to respond to these conflicting pressures, policymakers may have adopted the 'new view' on efficient taxation or exploited fiscal illusion on the part of taxpayers. 
According to the economic mainstream's traditional view, taxes on dividends and corporate profits increase the cost of capital for corporations, thereby depressing investment. Proponents of the 'new view' argue instead that taxes on dividends are less harmful than taxes on corporate profits because of globalized capital markets. If shareholders in one country demand higher returns because of an increasing tax burden, corporations will simply obtain funding from investors operating in - or through - tax havens. In contrast, rising taxes on corporate profits diminish dividends paid out to investors irrespective of their location, thereby driving up firms’ capital costs (Brys et al., 2016, pp. 36-38). Policymakers may thus have tried to limit the budgetary fallout from corporate tax cuts by shifting the tax burden to domestic shareholders. To control for the tax shifting conjecture, we include an interaction term of the dividend dummy with countries’ corporate tax rates.

Alternatively, policymakers may have wanted to signal compensatory fairness to voters by raising statutory taxes on capital owners irrespective of the actual impact of such reform on tax revenue and redistribution. Increasing the tax burden on dividends during a recession when little dividends are paid might have been a costless form of appeasement in a general context of fiscal austerity (Tooze, 2018, p. 464 ff.). Since previous research shows that demand for compensatory fairness is highest in countries experiencing a deep banking crisis (Limberg, 2019, pp. 7-9), we interact a binary crisis indicator with the dividend dummy to control for the appeasement conjecture. According to this indicator, a country experiences a banking crisis in a given year if at least two of the following six criteria are met: Extensive liquidity support, bank restructuring, significant bank nationalizations, significant guarantees, significant asset purchases and deposit freezes or bank holidays (Laeven \& Valencia, 2013, p. 229).

Finally, we need to exclude that tax increases on dividends are merely an artifact of increases in personal income tax (PIT). In many countries, the PIT applies to income from labor 
and capital. Hence, top marginal income tax rates and taxes on dividends are sometimes identical. This raises the possibility that policymakers, who wanted to increase taxes on relatively immobile labor, increased taxes on dividends in passing rather than on purpose. To control for the artifact conjecture, we use the indicator 'top tax rate' from table I.7 of the OECD tax database (OECD, 2019), which is 'the top statutory tax rate for the combined central and sub-central governments.' Again, we include the interaction term with the dividend dummy in the regression.

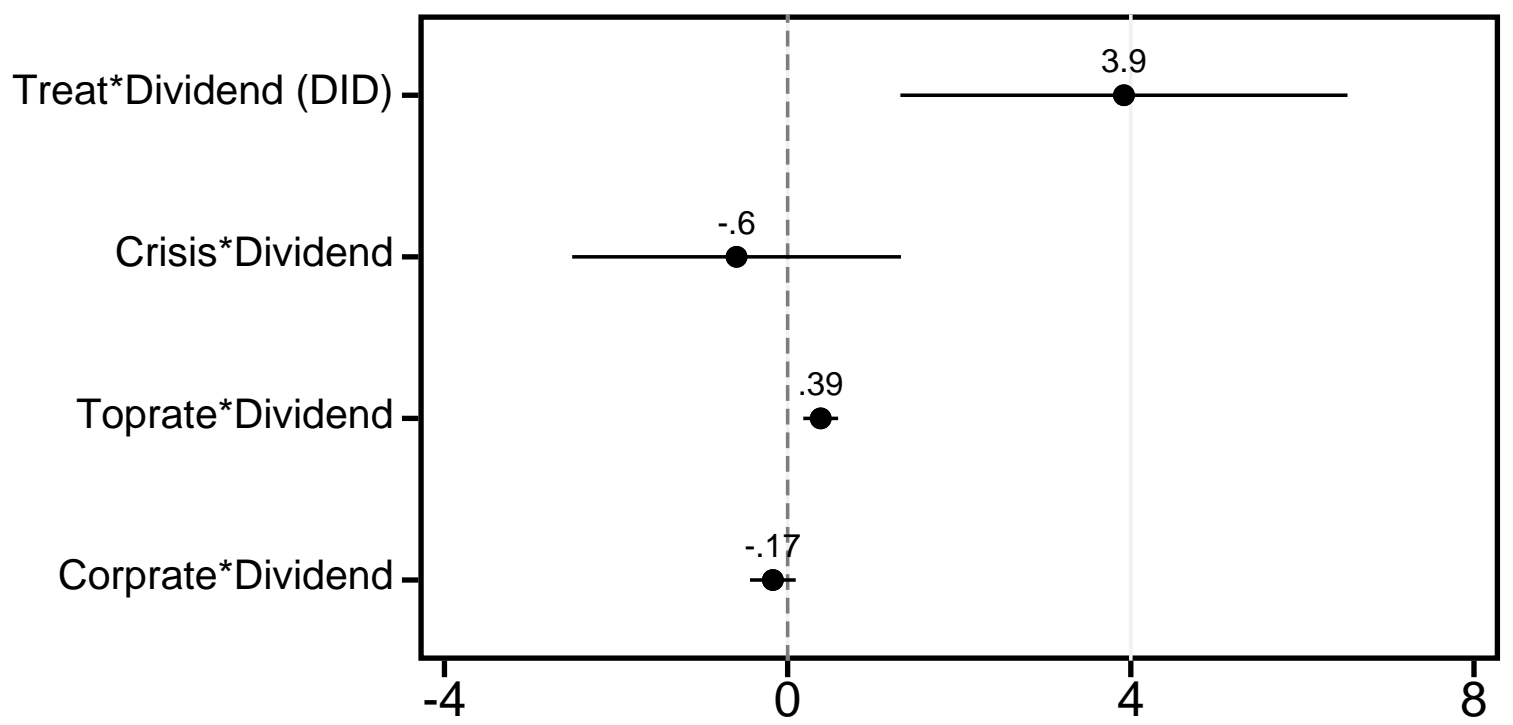

Figure 3: Difference in Difference Regression Results ${ }^{6}$

Figure 3 presents the results of our preferred specification. It shows a sizable and significant coefficient of the DID estimator suggesting that the average dividend tax rate is 3.9 percentage points higher than it would have been absent the treatment. In contrast, the interactions of the dividend dummy with the crisis indicator and countries' corporate tax rates are not significantly different from zero in any model in which they are included. Hence, neither demands for compensatory fairness nor a potential diffusion of the 'new view' among OECD governments sufficiently explain the break in trends of the mean tax rates on dividends and corporate profits. 
At the same time, the small but highly significant effect of the dividend dummy's interaction with countries' top PIT rates suggests that some of the increases in dividend tax rates may have been collateral damage from tax hikes on labor. Table A.1 in the online appendix shows that these results are robust to a range of different model specifications. In particular, they also hold with Finland and Norway included in the analysis (see Table A.1.1 in the online appendix).

The DID regression reveals a substantial impact of international cooperation on dividend tax rates. To explore the effect's development over time, we estimate a second model:

(2) taxrate $_{d c t}=\gamma_{c}+\lambda_{t}+\sum_{j=-m}^{q} \beta_{j}$ dividend $_{c t}(t=2009+j)+\beta_{2} X_{c t}+\epsilon_{c t}$

Instead of a single treatment effect, the model provides for $m$ 'leads' and $q$ 'lags' of the treatment. Hence, $\beta_{j}$ is the coefficient for the $j$ th lead or lag. Again, $X$ is a placeholder for our three control variables and standard errors are bootstrapped. We report regression results in Figure 4 and Table A.2 in the online appendix.

The reported DIDs relate to the reference point $t=2009$. The coefficients $\beta_{j}$ capture the difference in the evolution of tax rates imposed on dividends and tax rates imposed on corporate profits between 2009 and every lead and lag year. All lead coefficients are zero or indifferent from zero. This confirms the validity of the common trend assumption. The lag coefficients are bigger than the lead effects and statistically significant for almost all years following 2009 (the only exception is 2011). The coefficient for 2010, for instance, reflects that the gap between the mean tax rate on dividends and the mean tax rate on corporate profits narrowed by 1.9 percentage points between 2009 and 2010. The coefficient for 2017 contains our main result: International tax cooperation enabled an increase in the average tax rate on dividends by 4.5 percentage points between 2009 and 2017. 


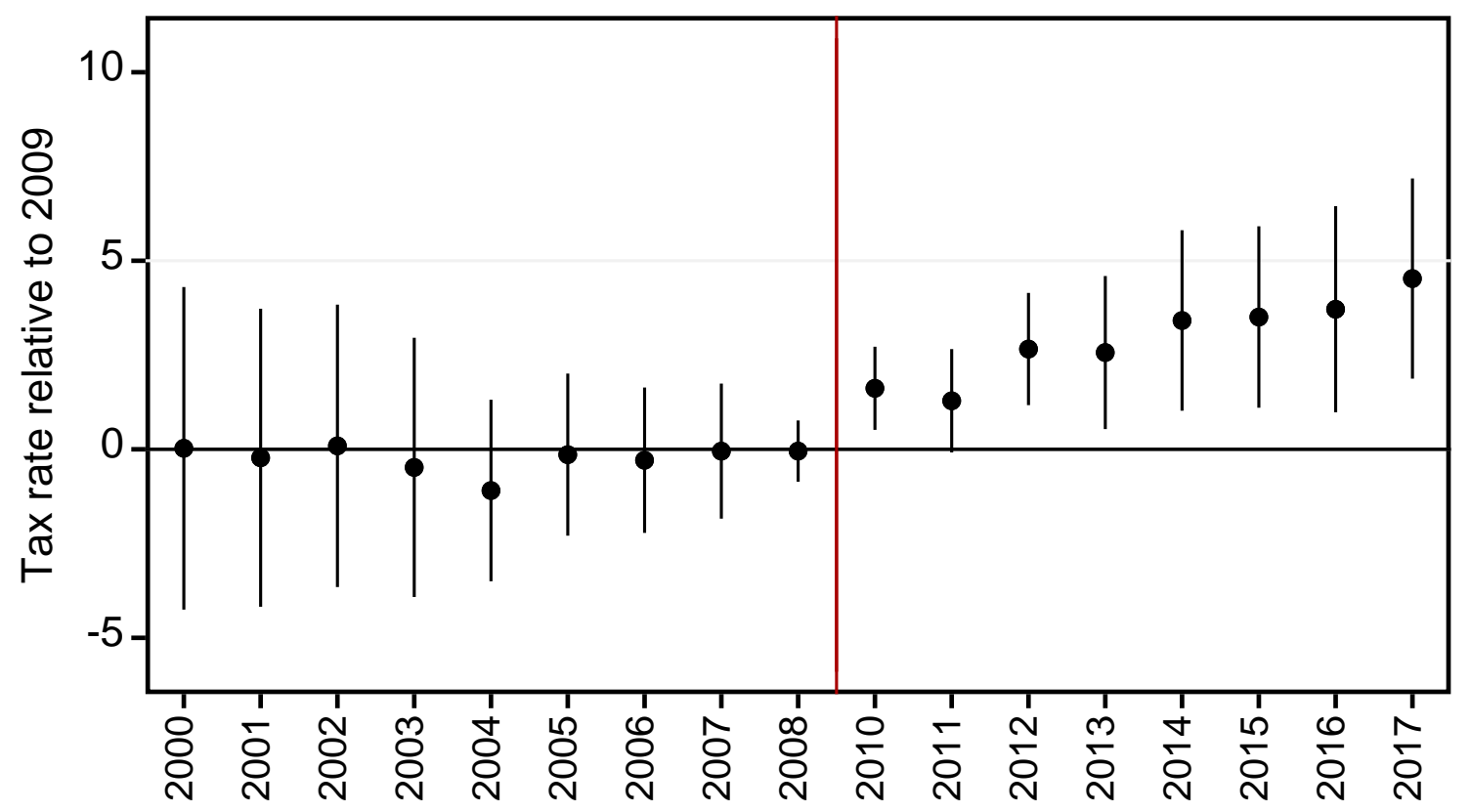

Figure 4: Differences in Differences to Reference Year $2009^{7}$

The development of the lag effects suggest that the treatment received by dividend tax rates from 2009 unfolded its effect over the course of several years. This matches the incremental process described in section 3, linking the G20's initial commitment to financial transparency to the eventual start of multilateral AEI in 2017. In particular, the coefficients for 2012 and 2014, which are substantially larger than the coefficients for the directly preceding years, suggest that the signature of the first FATCA IGAs and the multilateral adoption of the OECD CRS spurred the upward trend in tax rates on dividends. These findings remain fully intact with Finland and Norway included in the analysis (see Table A.2.1 in the online appendix).

\subsection{Comparing Variation of Tax Rates: A Structural Break in Dividend Tax Rates}

We argue that tax cooperation impacts national tax rates by reducing competitive pressure. Accordingly, the third and fourth empirical implications of our hypothesis are that (3) variation of tax rates across countries should decrease in both groups before 2009 as countries undercut each other and (4) increase in the treatment group thereafter as countries are released from tax 
competition. Figure 4 shows the absolute deviation from the mean of both rates over time. ${ }^{8}$ While the line for dividend tax rates exhibits a downward trend prior to 2009, the picture is less clear for corporate taxation. Nevertheless, there are strong reasons to believe that both kinds of capital taxes are subject to tax competition. As we show in the online appendix to this paper, the relatively flat line for corporate rates depicted here results from the fact that the decline of dividend rate variation is delayed relative to corporate rate variation. This in turn does not result from a lack of competitive pressure on dividend taxes prior to 2000 but from an institutional constraint: the integration of dividend taxation in the general PIT schedule at the beginning of the era of tax competition in the 1980s. Nevertheless, the figure makes clear that we do not have parallel trends of both tax rates.

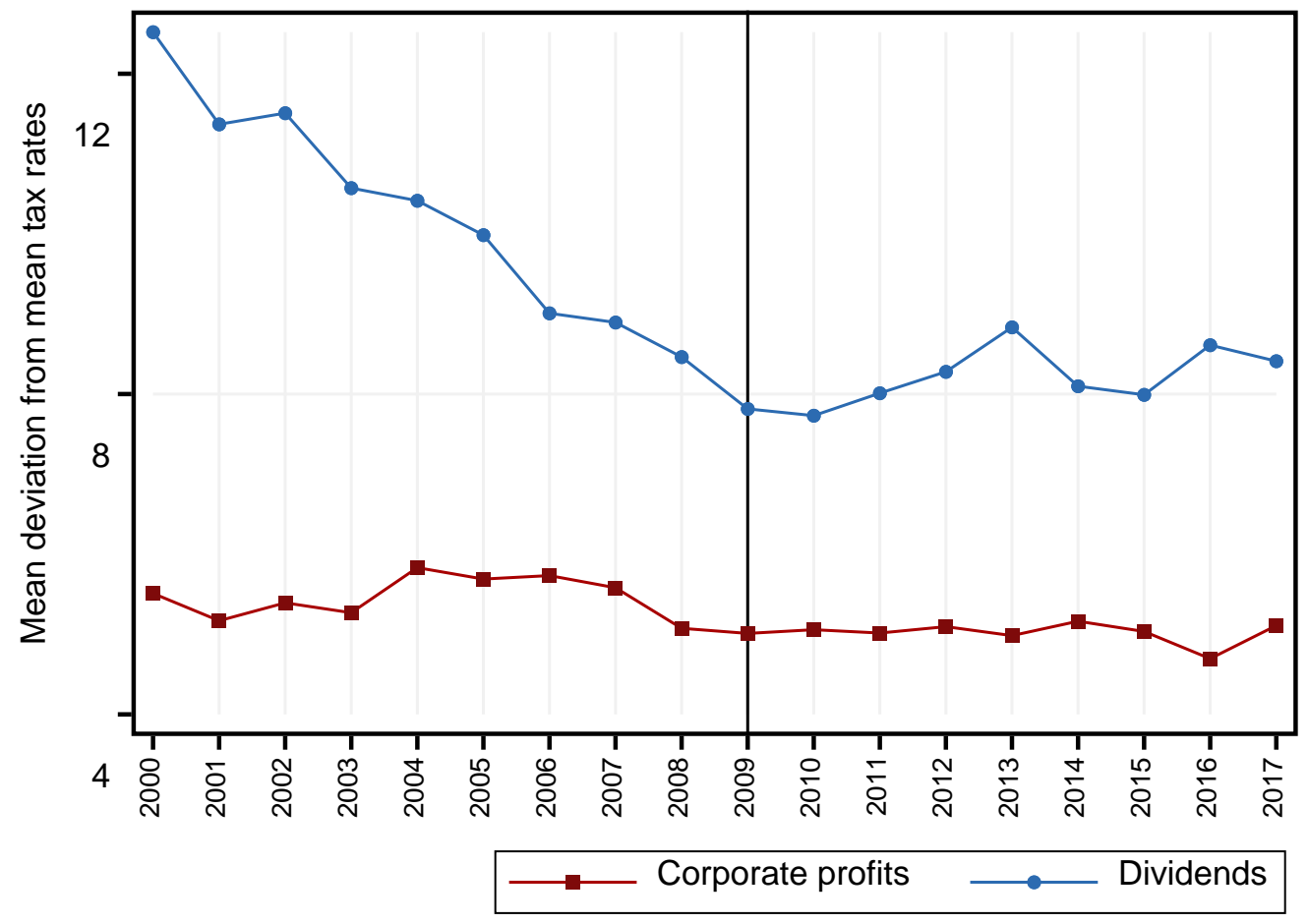

Figure 5: Deviation from the Mean of Tax Rates Imposed on Dividends and Corporate Profits in OECD Countries

Despite this qualification, figure 5 makes clear that competitive pressure on dividend taxes before 2009 was halted thereafter. Between that year and 2013 variation increased again and 
stabilized towards the end of the observation period. In contrast, competitive pressure on corporate tax rates apparently remained high after 2009. Overall, the graphical analysis provides initial evidence for our fourth empirical implication and weakly supports the third implication. Since trends in the variation of rates are not parallel before 2009, we cannot rely on the DID method to substantiate this initial evidence. To formally test the empirical implications, we instead search the two trends for structural change points. First a Levin-Lin-Chu unit-root test shows that we cannot reject the null hypothesis of non-stationarity for dividend tax rates, but finds stationarity for corporate rates. In order to identify the structural change points we run a set of linear regressions of the following form:

$$
\text { (3) } \text { mddtaxrate }_{c t}=\alpha+\beta_{0} \text { year }+\beta_{1} d u m_{t} * \text { year }+\beta_{2} d u m_{t}+\gamma_{c}+\epsilon_{c t}
$$

Whereby mddtaxrate $c$ is the (absolute) deviation of the tax rate in a country from the average rate of all countries in a given year $t$ for either dividends or corporate profits. year is a time variable for all years and $d u m_{t}$ is a dummy variable that takes the value 0 for all years prior to $t$ and 1 otherwise. Thus, year $* d u m_{t}$ is an interaction term to capture a structural break in the time trend. $\gamma_{c}$ are country fixed effects and $\epsilon_{c t}$ is an error term. To identify structural breaks we run one regression for every year as (potential) treatment year and separately for dividend taxes and corporation taxes. We report the estimated coefficients $\left(\beta_{1}\right)$ for regressions between 2005 and 2013 in Figure 6 and for all years in table A.3 of the online appendix. 

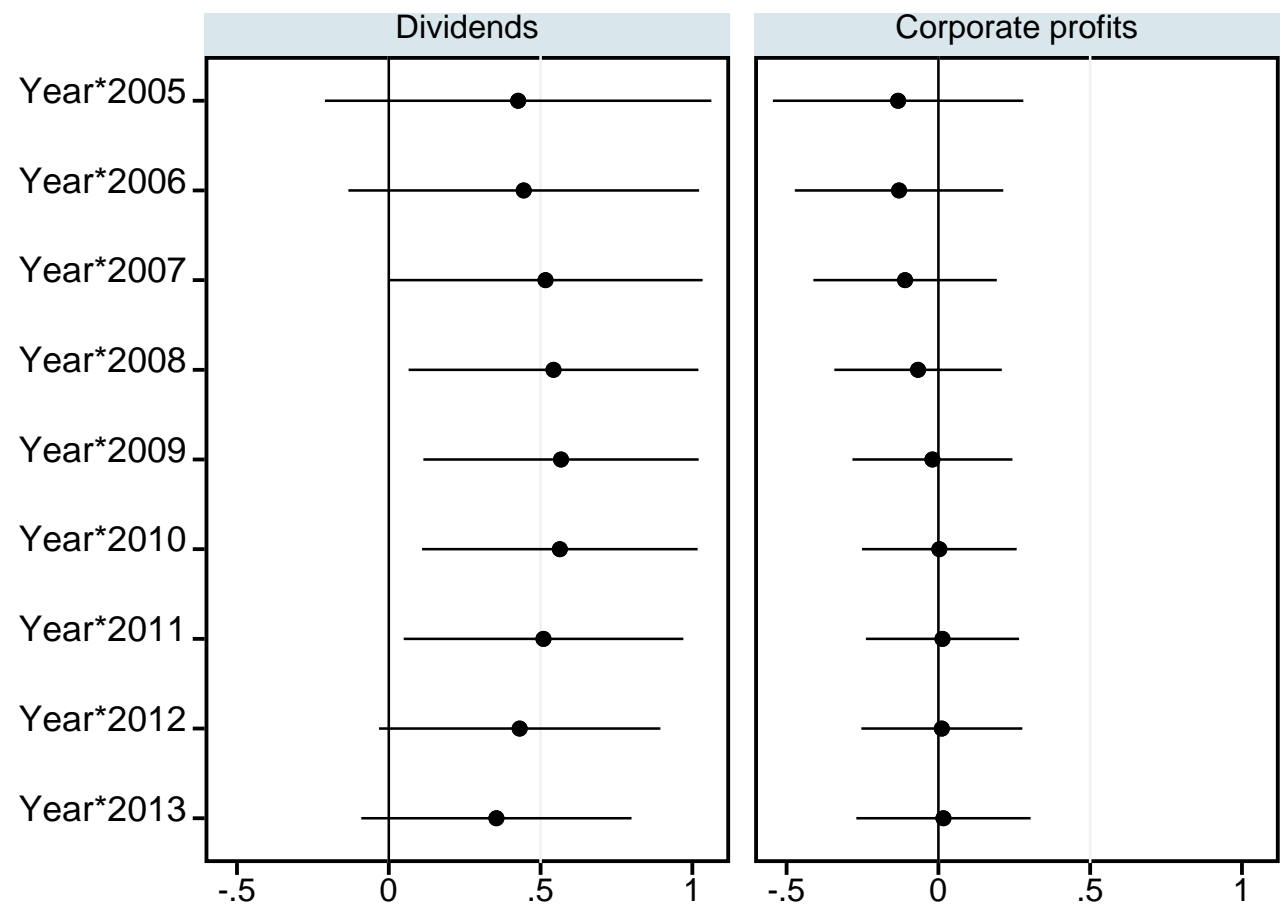

Figure 6: Coefficients of Interaction Dummy in Trend Regressions

We find that the trend over the entire observation period is negative and significant for dividends and flat and insignificant for corporate taxes (see the coefficient of Time in Table A.3 in the online appendix). ${ }^{9}$ Figure 6 shows that significant coefficients of the interaction term have the opposite direction of the overall time trend for dividends. Importantly, the coefficient reaches maximum size and highest statistical significance in 2009. Likewise, we find a number of substantial and significant deviations from the overall trend in subsequent years. In contrast, the coefficients of the interaction terms for corporate tax rates are smaller and insignificant for all years. For many years the direction of the effect is the same, i.e. negative, as in the overall time trend and there is no substantial and significant deviation from the overall trend in 2009. Hence, the structural break analysis supports implications 3 and 4 of our hypothesis. Similar results obtain, if we include Finland and Norway in the analysis. In this case, the interaction coefficient reaches its maximum size in 2010 (0.436), but very closely followed by 2009 (0.432) (Table A.3.1 in the online appendix). 


\subsection{Qualitative Evidence: Tax Reform in the United Kingdom}

In this section, we analyze the Labour government's tax reform of 2009 to illustrate the enabling role of international tax cooperation in actual policymaking. This reform is a most-likely case for the counterargument that domestic motivators cause increases in dividend taxation on their own, because it was implemented by a center-left government in the immediate aftermath of the financial crisis, which caused a comparatively deep recession in the UK, created voter demand for compensatory fairness (Limberg, 2018), and forced HM Treasury to spend 26.6\% of GDP on bank bailouts and fiscal stimulus (Tooze, 2018, pp. 168, 274). The reform is also an extreme case on the dependent variable, as it involved an increase in the net statutory tax rate on dividends at the shareholder level from 25 to 36.11 percentage points, the largest year-toyear increase in our dataset. We show that this reform was embedded in a context of enhanced international cooperation against financial secrecy, which raised the chancellor of the exchequer’s confidence in its revenue raising capacity.

In order to signal the ideological difference between Old and New Labour, Tony Blair had pledged not to increase income taxes, including on the highest incomes, during his term as prime minister. Ahead of general elections in 2005, the Labour party renewed this pledge (Kickert, 2012, p. 172). Accordingly, the net statutory top rate on dividend income remained constant at 25 percent between 1997 and 2009 (Maffini, 2013, p. 155). At the insistence of prime minister Gordon Brown, however, chancellor of the exchequer Alistair Darling abandoned the pledge in his 2009 budget (Darling, 2012, p. 230 ff.). Together with the top rate of income tax, which increased from 40 to 50 percent, he raised the net statutory tax rate on dividends at the shareholder level to 36.11 percent (Maffini, 2013, p. 155). In his budget speech, Darling justified higher taxes on top incomes with the need to bring down borrowing and the benefits top earners had reaped from economic expansion before the crisis (Clark, 2009). Before the Treasury Committee in the House of Commons, Darling further elaborated that 
'I raised the top rate and brought it forward to 50 pence [because] we do need to set ourselves on a path where we can reduce the amount of borrowing [...]. I do not think it is unfair, given that people at that top end, and we are talking about the top $1 \%$, have seen their incomes go up quite dramatically over the last 10 to 15 years, that we should not say to them, "Look, you've got to make a contribution”' (Treasury Committee, 2009, p. 43).

But some committee members were not convinced these goals could be reached, as projections by HM Revenue and Customs suggested that, owing to tax evasion and avoidance, tax increases on top incomes would only deliver 31 percent of their potential yield. In response to their criticism, Darling clarified that ' $\mathrm{I}$ am raising revenue both in indirect taxes and from next year from those earning over $£ 100,000$ in direct taxes, and of course I will always be vigilant about loopholes and indeed we announced various measures in the Budget there' (Treasury Committee, 2009, p. 45). Next to removing some domestic loopholes, the 2009 budget also included a section on 'protecting tax revenues,' summarizing recent advances by the G20 and OECD in improving financial transparency. Against this background, the budget announced a 'New Disclosure Opportunity,' allowing holders of offshore accounts to declare unpaid taxes and settle debts without additional fines. In combination, these proposals should 'raise over $£ 1$ billion during the period 2009-10 to 2011-12, and protect a further $£ 3$ billion of tax receipts a year by 2010-11 from tax evasion and avoidance’ (HM Treasury, 2009a, p. 108).

As we expect, international tax cooperation did not motivate the increase in the top tax rate on dividend income. It rather enabled HM Treasury to flank the reform with anti-evasion measures that were supposed to increase its effective revenue yield, providing the chancellor with a counterargument to criticism from members of parliament. The British government also commissioned an investigation into the information exchange practices of its Crown Dependencies and Overseas Territories, after the G20 had announced countermeasures to financial secrecy (Barker, 2009; Foot, 2009, p. 5). The final report published in October 2009 concluded that 'the nine jurisdictions must show a commitment not just to the letter but also to the spirit 
of international standards [and] make an early commitment, with a timetable for implementation, to automatic exchange of information' (Foot, 2009, pp. 36-37). In reaction to the report and further progress at the G20, the Labour government implemented tougher penalties for tax evaders failing to make use of the disclosure opportunity (HM Treasury, 2009b, pp. 90-91).

\section{Conclusion}

International tax cooperation makes a difference. Since the G20 pursues the objective of establishing financial transparency, thereby reducing the scope for tax evasion by individuals with foreign accounts, the downward trend in dividend tax rates observed between 2000 and 2009 has reversed. In contrast, corporate tax rates - still subject to the pressures of tax competition, as initiatives against tax avoidance remain unsuccessful - continue to fall. Our statistical analysis estimates that international tax cooperation accounts for a 4.5 percentage point increase in dividend tax rates until 2017. This implies that governments regained discretion over the level of tax where international cooperation reduces the risk of capital flight.

These findings bear on current debates about the role of taxation in the fight against income inequality. While these discussions are often limited to national institutions and policies only (but see Piketty, 2013, p. 835 ff.), we show that the creation of enabling international institutions and policies are a necessary precondition for progress. If policymakers' aim is to end the neoliberal and regressive tax policies that have characterized recent decades going beyond the AEI and creating an equally effective remedy to corporate tax avoidance is essential. In this regard, replacing separate entity accounting and the ALS with unitary taxation, as currently proposed by the European Commission in its proposal for a common consolidated corporate tax base (CCCTB), seems to be the most ambitious but also the most promising way forward. 
In addition to this immediate policy implication, our findings bear on two debates in the international and comparative political economy literature. First, the article brings new evidence to the debate on the diffusion of neoliberal policies. In taxation, some have argued that the wave of rate-lowering and base-broadening reforms since the 1980s was mainly caused by the rising influence of neoliberal ideas (Steinmo, 2003; Swank, 2006). Others attributed the reforms to material and structural constraints resulting from the globalization of capital markets and international tax competition (Ganghof, 2006, p. 31 ff.; Genschel, 2002). Our results suggest the two interact. Whereas economic ideas - such as recent arguments for a return to progressive taxation (Atkinson, 2015; Chetty \& Saez, 2010; Piketty, 2013) - may influence the tax policy preferences of decisive actors, they only produce change if structural constraints on national tax policy are removed. Hence, we can conclude that international tax cooperation and new policy ideas are both necessary - but only their combination is sufficient - for a departure from neoliberal tax policy.

Second, it is instructive to link our findings to debates on the effectiveness of international cooperation and the backlash against globalization. Especially in situations marked by public good or common pool resource problems (like many issues in environmental protection), scholars often use states’ compliance with self-binding agreements as an indicator for effectiveness. Some argue, however, that compliance does not tell us enough about effectiveness, since agreements may be too 'shallow' (Downs et al., 1996). Against this background, scholars alternatively try to gauge the impact of cooperation on the natural environment (see (Young, 2001). Our analysis resembles the latter approach in that we assess actual outcomes (tax rate changes) rather than compliance with the AEI. It differs, however, in that effective international cooperation does not directly constrain national policy choices, as is usually the case in environmental protection. Instead, it expands the domestic policy space. Rather than being pressured by tax competition to lower taxes on dividends, governments now have real discretion over the applicable rate. 
In this sense, the AEI is a model for international cooperation that is normatively desirable in a political environment marked by popular disenchantment with economic globalization. Dani Rodrik (2011) has argued that the current trajectory of 'hyperglobalization' is unsustainable because it puts all states into a 'golden straitjacket' that makes it impossible to compensate the losers of globalization at the national level. He and others instead advocate a normative vision of 'sensible globalization,' providing national governments with enough leeway to pursue policies in accordance with voter preferences (Laborde \& Ronzoni, 2016). We submit that the AEI can be one element in a corresponding strategy. By showing that it is effective, we provide evidence for its real-world feasibility. Our findings suggest that strengthening the capacity of national governments to adequately compensate 'globalization losers' will need more - not less - international cooperation than we have seen in the past. In the face of rising nationalist and protectionist tendencies it is high time for internationalists and international institutions to act on this insight. 


\section{Notes}

${ }^{1}$ See figure 2.

${ }^{2}$ In this article, we do not empirically investigate the full causal chain but focus on the intervening variable only. As discussed in part 4, our identification strategy aims at isolating the average effect of international tax cooperation on tax rates imposed on dividends. In a companion paper (Ahrens et al., 2020), we investigate the empirical interaction between fiscal transparency and the domestic factors to also explain tax rate variation across countries.

${ }^{3}$ Bilateral conversation in the sidelines of the State of the Union Conference in Florence, 9 May 2014.

${ }^{4}$ Interview with senior German tax official, Berlin, 15 March 2015.

${ }^{5}$ See the online appendix for more information on the imputation system.

${ }^{6}$ For details, see table A.1 in the appendix

${ }^{7}$ For details, see table A.2 in the appendix.

${ }^{8}$ The literature on policy convergence often uses the standard deviation or the coefficient of variation (e.g. Hays, 2003, p. 81; Simmons et al., 2006, p. 784). For our purposes the absolute deviation from the mean is more appropriate. First, it is less sensitive to individual outliers (Holzinger, 2006, p. 277) Second, the deviation from the mean (for each year and tax) can be obtained for each individual observation. The deviation from the mean is thus better suited for inclusion as a dependent variable (Holzinger, 2006, p. 280).

${ }^{9}$ Extending the observation period, we find that the variation of corporate rates also exhibits a downward trend. See section 2 of the online appendix. 


\section{References}

Ahrens, L., \& Bothner, F. (2019). The Big Bang: Tax Evasion After Automatic Exchange of Information Under FATCA and CRS. New Political Economy. https://doi.org/10.1080/13563467.2019.1639651

Ahrens, L., Bothner, F., Hakelberg, L., \& Rixen, T. (2020). New room to maneuver? National tax policy under increasing financial transparency. Socio-Economic Review. https://doi.org/10.1093/ser/mwaa007

Alstadsæter, A., Johannesen, N., \& Zucman, G. (2019). Tax Evasion and Inequality. American Economic Review, 109(6), 2073-2103.

Alvaredo, F., Chancel, L., Piketty, T., Saez, E., \& Zucman, G. (2018). World Inequality Report 2018. World Inequality Lab. https://wir2018.wid.world/files/download/wir2018-fullreport-english.pdf

Atkinson, A. B. (2015). Inequality: What Can Be Done. Harvard University Press.

Balzli, B., Bartsch, M., Kurbjuweit, D., Neumann, C., Schmidt, B., \& Stark, H. (2008). Ein braver Sohn. Der Spiegel, 2008(9), Deutschland; Affären; S. 30.

Barker, A. (2009, October 4). Brown warns tax havens to comply. Financial Times. https://www.ft.com/content/77e557a2-25a8-11de-be57-00144feabdc0

Basinger, S. J., \& Hallerberg, M. (2004). Remodeling the Competition for Capital: How Domestic Politics Erases the Race to the Bottom. The American Political Science Review, 98(2), 261-276.

Bergin, T. (2012, October 15). Special Report: How Starbucks avoids UK taxes. Reuters. https://uk.reuters.com/article/us-britain-starbucks-tax-idUKBRE89E0EX20121015

Bertrand, M., Duflo, E., \& Mullainathan, S. (2004). How Much Should We Trust DifferencesIn-Differences Estimates? The Quarterly Journal of Economics, 119(1), 249-75.

Bird, R. M. (1980). Tax Incentives for Investment: The State of the Art. Canadian Tax Foundation. 
Brys, B., Perret, S., Thomas, A., \& O’Reilly, P. (2016). Tax Design for Inclusive Economic Growth [OECD Taxation Working Papers]. Organisation for Economic Co-operation and Development. http://www.oecd-ilibrary.org/content/workingpaper/5jlv74ggk0g7en

Büttner, T., \& Thiemann, M. (2017). Breaking regime stability? The Politicization of Expertise in the OECD/G20 process on BEPS and the potential transformation of international taxation. Accounting, Economics, and Law: A Convivium, 7(1).

CDU, CSU, \& SPD. (2018). Ein neuer Aufbruch für Europa; Eine neue Dynamik für Deutschland; Ein neuer Zusammenhalt für Unser Land. Bundesregierung. https://www.bundesregierung.de/resource/blob/975226/847984/5b8bc23590d4cb2892b31c987ad672b7/2018-03-14-koalitionsvertrag-data.pdf?download=1

Chetty, R., \& Saez, E. (2010). Dividend and Corporate Taxation in an Agency Model of the Firm. American Economic Journal: Economic Policy, 2(3), 1-31.

Christensen, R. C., \& Hearson, M. (2019). The new politics of global tax governance: Taking stock a decade after the financial crisis. Review of International Political Economy, 26(5), 1068-1088.

Clark, T. (2009, April 22). Analysis of Alistair Darling’s 2009 budget speech. The Guardian. http://www.theguardian.com/uk/2009/apr/22/budget-2009-alistair-darling-speech

Clausing, K. A. (2007). Corporate tax revenues in OECD countries. International Tax and Public Finance, 14(2), 115-133.

Cobham, A., \& Janský, P. (2018). Global distribution of revenue loss from corporate tax avoidance: Re-estimation and country results. Journal of International Development, 30(2), 206-232. 
Cobham, A., \& Janský, P. (2019). Measuring misalignment: The location of US multinationals’ economic activity versus the location of their profits. Development Policy Review, 37(1), 91-110.

Creighton, A. (2016, July 21). A Shrinking World Spurs Calls to Rewrite the Tax Guidebook. WSJ. https://blogs.wsj.com/economics/2016/07/21/a-shrinking-world-spurs-calls-torewrite-the-tax-guidebook/

Crivelli, E., De Mooij, R., \& Keen, M. (2016). Base erosion, profit shifting and developing countries. FinanzArchiv: Public Finance Analysis, 72(3), 268-301.

Cusack, T. R. (1999). Partisan Politics and Fiscal Policy. Comparative Political Studies, 32(4), 464-486.

Darling, A. (2012). Back from the Brink: 1000 Days at Number 11 (Main). Atlantic Books.

Devereux, M. P., Lockwood, B., \& Redoano, M. (2008). Do countries compete over corporate tax rates? Journal of Public Economics, 92(5-6), 1210-1235.

Dietsch, P., \& Rixen, T. (2016). Global Tax Governance: What's wrong with it and how to fix it. ECPR press.

Downs, G. W., Rocke, D. M., \& Barsoom, P. N. (1996). Is the good news about compliance good news about cooperation? International Organization, 50(3), 379-406.

Dyreng, S. D., Hanlon, M., Maydew, E. L., \& Thornock, J. R. (2017). Changes in corporate effective tax rates over the past 25 years. Journal of Financial Economics, 124(3), 441463.

Egger, P. H., Nigai, S., \& Strecker, N. M. (2019). The Taxing Deed of Globalization. American Economic Review, 109(2), 353-390.

Emmenegger, P. (2017). Swiss banking secrecy and the problem of international cooperation in tax matters: A nut too hard to crack? Regulation \& Governance, 11(1), 24-40.

Fehling, D. (2014). Fehling: Die steuerlichen Herausforderungen bei der Digitalen Wirtschaft. Internationales Steuerrecht, 18, 638-643. 
Finley, R. (2016, August 6). BEPS Report on Transfer Pricing “Could Have Been Worse,” Hickman Says | TaxNotes.com. Tax Analysts. http://www.taxnotes.com/worldwide-taxdaily/transfer-pricing/beps-report-transfer-pricing-could-have-been-worse-hickmansays/2016/06/08/hb7c

Foot, M. (2009). Final report of the independent Review of British Offshore Financial Centres. HM Treasury. https://www.gov.im/media/624053/footreport.pdf

G20 Leaders. (2009). London Declaration. http://www.g20.utoronto.ca/2009/2009communique0402.html

G20 Leaders. (2013). Tax Annex to the St. Petersburg G20 Leaders' Declaration. G20. https://www.oecd.org/g20/summits/saint-petersburg/Tax-Annex-St-Petersburg-G20Leaders-Declaration.pdf

Ganghof, S. (2006). The Politics of Income Taxation: A Comparative Analysis. ECPR Press.

Garrett, G., \& Mitchell, D. (2001). Globalization, government spending and taxation in the OECD. European Journal of Political Research, 39(2), 145-177.

Genschel, P. (2002). Globalization, Tax Competition, and the Welfare State. Politics \& Society, 30(2), 245-275.

Genschel, P., \& Schwarz, P. (2011). Tax competition: A literature review. Socio-Economic Review, 9(2), 339-370.

Genschel, P., \& Schwarz, P. (2013). Tax Competition and Fiscal Democracy. In W. Streeck \& A. Schäfer (Eds.), Politics in the age of austerity. Polity.

Government Accountability Office. (2007). Tax Compliance: Qualified Intermediary Program Provides Some Assurance That Taxes on Foreign Investors Are Withheld and Reported, but Can Be Improved. http://www.gao.gov/products/GAO-08-99

Grinberg, I. (2015). The new international tax diplomacy. Geo. LJ, 104, 1137. 
Hakelberg, L. (2015). The power politics of international tax co-operation: Luxembourg, Austria and the automatic exchange of information. Journal of European Public Policy, 22(3), 409-428.

Hakelberg, L. (2016). Redistributive Tax Cooperation: Automatic exchange of information, US Power, and the absence of joint gains. In P. Dietsch \& T. Rixen (Eds.), Global Tax Governance. ECPR Press.

Hakelberg, L. (2020). The Hypocritical Hegemon: How the United States Shapes Global Rules Against Tax Evasion and Avoidance. Cornell University Press.

Hakelberg, L., \& Schaub, M. (2018). The redistributive impact of hypocrisy in international taxation. Regulation \& Governance, 12(3), 353-370.

Handelsblatt. (2006, September 19). Steinbrück will mit 25 Prozent einsteigen. http://www.handelsblatt.com/politik/deutschland/abgeltungssteuer-steinbrueck-will-mit-25-prozenteinsteigen/2708232.html

Hanlon, M., Maydew, E. L., \& Thornock, J. R. (2015). Taking the Long Way Home: U.S. Tax Evasion and Offshore Investments in U.S. Equity and Debt Markets. The Journal of Finance, 70(1), 257-287.

Harding, M., \& Marten, M. (2018). Statutory tax rates on dividends, interest and capital gains. https://www.oecd-ilibrary.org/content/paper/1aa2825f-en

Harrington, B. (2016). Capital without Borders: Wealth Managers and the One Percent. Harvard University Press.

Hays, J. C. (2003). Globalization and Capital Taxation in Consensus and Majoritarian Democracies. World Politics, 56(1), 79-113.

Hearson, M., \& Prichard, W. (2018). China's challenge to international tax rules and the implications for global economic governance. International Affairs, 94(6), 1287-1307. 
Herzfeld, M. (2015, June 22). News Analysis: The U.S. Treasury and the BEPS Mess TaxNotes.com. Tax Analysts. http://www.taxnotes.com/worldwide-tax-daily/base-erosion-and-profit-shifting-beps/news-analysis-us-treasury-and-bepsmess/2015/06/22/h2k6?highlight=BEPS\&United\%20States\&Robert\%20Stack

HM Treasury. (2009a). Budget 2009: Building Britain’s future (HC 407). Her Majesty’s Treasury. https://assets.publishing.service.gov.uk/government/uploads/system/uploads/attachment_data/file/250681/0407.pdf

HM Treasury. (2009b). Pre-Budget Report: Securing the recovery: Growth and opportunity. Her Majesty’s Treasury. https://assets.publishing.service.gov.uk/government/uploads/system/uploads/attachment_data/file/238510/7747.pdf

Holzinger, K. (2006). Methodological Pitfalls of Convergence Analysis. European Union Politics, 7(2), 271-287.

Holzinger, K., Knill, C., \& Sommerer, T. (2008). Environmental Policy Convergence: The Impact of International Harmonization, Transnational Communication, and Regulatory Competition. International Organization, 62(4), 553-587.

Huizinga, H., \& Nicodème, G. (2004). Are international deposits tax-driven. Journal of Public Economics, 88(6), 1093-1118.

International Monetary Fund. (2014). Fiscal Policy and Income Inequality (IMF Policy Paper). International Monetary $\quad$ Fund. https://www.imf.org/external/np/pp/eng/2014/012314.pdf

IRS. (2000). Rev. Proc. 2000-12 Application Procedures for Qualified Intermediary Status Under Section 1441; Final Qualified Intermediary Withholding Agreement. Internal Revenue Service Cumulative Bulletin, 2000(1), 387-413. 
IRS. (2016). Offshore Compliance Programs Generate \$8 Billion; IRS Urges People to Take Advantage of Voluntary Disclosure Programs. https://www.irs.gov/uac/newsroom/offshore-compliance-programs-generate-8-billion-irs-urges-people-to-take-advantage-ofvoluntary-disclosure-programs

Jansky, P., Meinzer, M., \& Palanský, M. (2018). Is Panama Really Your Tax Haven? Secrecy Jurisdictions and the Countries They Harm (SSRN Scholarly Paper ID 3267366). Social Science Research Network. https://papers.ssrn.com/abstract=3267366

Johannesen, N. (2014). Tax evasion and Swiss bank deposits. Journal of Public Economics, 111, 46-62.

Johannesen, N., Langetieg, P., Reck, D., Risch, M., \& Slemrod, J. (2018). Taxing Hidden Wealth: The Consequences of U.S. Enforcement Initiatives on Evasive Foreign Accounts (Working Paper No. 24366). National Bureau of Economic Research.

Johannesen, N., \& Zucman, G. (2014). The end of bank secrecy? An evaluation of the G20 tax haven crackdown. American Economic Journal: Economic Policy, 6(1), 65-91.

Kickert, W. (2012). How the UK government responded to the fiscal crisis: An outsider's view. Public Money \& Management, 32(3), 169-176.

Kreienbaum, M. (2014). Kreienbaum: Base Erosion and Profit Shifting (BEPS): Erste Ergebnisse werden G20-Finanzministern vorgelegt. Internationales Steuerrecht, 18, 637638.

Laborde, C., \& Ronzoni, M. (2016). What is a Free State? Republican Internationalism and Globalisation. Political Studies, 64(2), 279-296.

Laeven, L., \& Valencia, F. (2013). Systemic banking crises database. IMF Economic Review, 61(2), 225-270.

Levin, C., \& Coleman, N. (2008). TAX HAVEN BANKS AND U.S. TAX COMPLIANCE. United States Senate. http://www.gpo.gov/fdsys/pkg/CHRG-110shrg44127/html/CHRG110shrg44127.htm 
Lierse, H., \& Seelkopf, L. (2016). Room to Manoeuvre? International Financial Markets and the National Tax State. New Political Economy, 21(1), 145-165.

Limberg, J. (2018). What's fair? Preferences for tax progressivity in the wake of the financial crisis. Journal of Public Policy, 1-23.

Limberg, J. (2019). “Tax the Rich”? The Financial Crisis, Fiscal Fairness, and Progressive Income Taxation. European Political Science Review: EPSR, Online First.

Lips, W. (2019). Great powers in global tax governance: A comparison of the US role in the CRS and BEPS. Globalizations, 16(1), 104-119.

Maffini, G. (2013). Corporate tax policy under the Labour government, 1997-2010. Oxford Review of Economic Policy, 29(1), 142-164.

Martin, J. (2015, December 6). US disappointed with BEPS plan guidance, Treasury officials say. MNE Tax. http://mnetax.com/us-officials-detail-position-on-beps-output-9269

Mooij, R. A. de, \& Ederveen, S. (2008). Corporate tax elasticities: A reader’s guide to empirical findings. Oxford Review of Economic Policy, 24(4), 680-697. https://doi.org/10.1093/oxrep/grn033

Murphy, R. (2009, April 19). Google's tax. Tax Research UK. https://www.taxresearch.org.uk/Blog/2009/04/19/googles-tax/

OECD. (2009). A progress report on the jurisdictions surveyed by the OECD Global Forum in implementing the internationally agreed tax standard. http://www.oecd.org/ctp/42497950.pdf

OECD. (2013). Action Plan on Base Erosion and Profit Shifting. OECD Publishing. https://www.oecd.org/ctp/BEPSActionPlan.pdf

OECD. (2014a). BEPS Actions 8, 9 and 10: Discussion Draft on Revisions to Chapter I of the Transfer Pricing Guidelines (Including Risk, Recharacterisation, and Special Measures). OECD Publishing. 
OECD. (2014b). Discussion Draft on Transfer Pricing Documentation and CbC Reporting. OECD Publishing.

OECD. (2014c). Public Discussion Draft—BEPS Action 7: Preventing the Artificial Avoidance of PE Status. OECD Publishing.

OECD. (2015). Preventing the Artificial Avoidance of Permanent Establishment Status, Action 7-2015 Final Report. OECD Publishing. http://www.oecd-ilibrary.org/taxation/preventing-the-artificial-avoidance-of-permanent-establishment-status-action-7-2015-final-report_9789264241220-en

OECD. (2017). Model Tax Convention on Income and on Capital, Condensed Version 2017. OECD Publishing.

OECD. (2018). CRS by jurisdiction. https://www.oecd.org/tax/automatic-exchange/crs-implementation-and-assistance/crs-by-jurisdiction/crs-by-jurisdiction-2018.htm

OECD. (2019). OECD Tax Database. OECD. http://www.oecd.org/tax/tax-policy/tax-database.htm

Omartian, J. D. (2017). Do Banks Aid and Abet Asset Concealment: Evidence from the Panama Papers. Available at SSRN 2836635.

Palan, R., Murphy, R., \& Chavagneux, C. (2010). Tax havens: How globalization really works. Cornell University Press.

Picciotto, S. (1992). International Business Taxation: A Study in the Internationalisation of Business Regulation. Weidenfield \& Nicolson.

Picciotto, S. (2015). Indeterminacy, Complexity, Technocracy and the Reform of International Corporate Taxation. Social \& Legal Studies, 24(2), 165-184.

Piketty, T. (2013). Le capital au XXIe siècle. Seuil.

Piketty, T., Saez, E., \& Stantcheva, S. (2014). Optimal Taxation of Top Labor Incomes: A Tale of Three Elasticities. American Economic Journal: Economic Policy, 6(1), 230-271. 
Piketty, T., Saez, E., \& Zucman, G. (2018). Distributional National Accounts: Methods and Estimates for the United States. The Quarterly Journal of Economics, 133(2), 553-609. Plümper, T., Troeger, V. E., \& Winner, H. (2009). Why is There No Race to the Bottom in Capital Taxation? International Studies Quarterly, 53(3), 761-786.

Rixen, T. (2008). The political economy of international tax governance. Palgrave Macmillan. Rixen, T., \& Schwarz, P. (2012). How Effective is the European Union's Savings Tax Directive? Evidence from Four EU Member States*. JCMS: Journal of Common Market Studies, 50(1), 151-168.

Rodrik, D. (2011). The Globalization Paradox: Democracy and the Future of the World Economy. W. W. Norton \& Company.

Rodrik, D. (2018). Populism and the economics of globalization. Journal of International Business Policy, 1(1), 12-33.

Saez, E., \& Zucman, G. (2019). The Triumph of Injustice: How the Rich Dodge Taxes and How to Make Them Pay. Norton \& Company.

Sandford, C. T. (1993). Successful tax reform: Lessons from an Analysis of Tax Reform in Six Countries. Fiscal Publications.

Scheve, K., \& Stasavage, D. (2016). Taxing the Rich: A History of Fiscal Fairness in the United States and Europe. Princeton Univers. Press.

Seabrooke, L., \& Wigan, D. (2016). Powering ideas through expertise: Professionals in global tax battles. Journal of European Public Policy, 23(3), 357-374.

Seabrooke, L., \& Wigan, D. (2017). The governance of global wealth chains. Review of International Political Economy, 24(1), 1-29.

Simmons, B. A., Dobbin, F., \& Garrett, G. (2006). Introduction: The international diffusion of liberalism. International Organization, 60(4), 781-810.

Steinmo, S. (2003). The Evolution of Policy Ideas: Tax Policy in the 20th Century. The British Journal of Politics and International Relations, 5(2), 206-236. 
Stewart, D. D. (2014, March 26). Stack Describes U.S. Goals and Concerns on BEPS Drafts. Tax Analysts. http://www.taxnotes.com/beps-expert/information-reporting/stack-describes-us-goals-and-concerns-beps-drafts/2014/03/26/16717256?highlight=BEPS\&United\%20States\&Robert\%20Stack

Swank, D. (2006). Tax Policy in an Era of Internationalization: Explaining the Spread of Neoliberalism. International Organization, 60(4), 847-882.

Swank, D., \& Steinmo, S. (2002). The New Political Economy of Taxation in Advanced Capitalist Democracies. American Journal of Political Science, 46(3), 642-655.

Tooze, A. (2018). Crashed: How a Decade of Financial Crises Changed the World (Reprint edition). Allen Lane.

Tørsløv, T., Wier, L., \& Zucman, G. (2018). The Missing Profits of Nations (Working Paper No. 24701). National Bureau of Economic Research.

Treasury Committee. (2009). Budget 2009: Eighth Report of Session 2008-09, Volume II, Oral and written evidence (HC 438-II). House of Commons. https://publications.parliament.uk/pa/cm200809/cmselect/cmtreasy/438/438ii.pdf

Widmaier, W. W. (2016). Economic Ideas in Political Time. Cambridge University Press.

Young, O. R. (2001). Inferences and Indices: Evaluating the Effectiveness of International Environmental Regimes. Global Environmental Politics, 1(1), 99-121.

Zodrow, G. R., \& Mieszkowski, P. (1986). Pigou, Tiebout, property taxation, and the underprovision of local public goods. Journal of Urban Economics, 19(3), 356-370.

Zucman, G. (2013). The Missing Wealth of Nations: Are Europe and the U.S. net Debtors or net Creditors?*. The Quarterly Journal of Economics, 128(3), 1321-1364. 


\section{Online Appendix}

\section{Regression Tables and Robustness Checks}

Table A.1: Differences in differences to reference year 2009 (without Finland and Norway) ${ }^{1}$

\begin{tabular}{|c|c|c|c|c|c|}
\hline VARIABLES & $\begin{array}{c}(1) \\
\text { Model } 1 \\
\end{array}$ & $\begin{array}{c}(2) \\
\text { Model } 2 \\
\end{array}$ & $\begin{array}{c}(3) \\
\text { Model } 3 \\
\end{array}$ & $\begin{array}{c}(4) \\
\text { Model } 4 \\
\end{array}$ & $\begin{array}{c}(5) \\
\text { Model } 5 \\
\end{array}$ \\
\hline Treat & $\begin{array}{c}-3.923^{* * *} \\
(0.540)\end{array}$ & $\begin{array}{c}-3.779 * * * \\
(0.556)\end{array}$ & $\begin{array}{c}-3.922 * * * \\
(0.542)\end{array}$ & $\begin{array}{c}-3.923^{* * *} \\
(0.553)\end{array}$ & $\begin{array}{c}-3.803 * * * \\
(0.597)\end{array}$ \\
\hline Treat*Dividend (DID) & $\begin{array}{c}4.497 * * * \\
(1.332)\end{array}$ & $\begin{array}{c}4.671 * * * \\
(1.370)\end{array}$ & $\begin{array}{c}4.501 * * * \\
(1.187)\end{array}$ & $\begin{array}{c}4.463 * * * \\
(1.530)\end{array}$ & $\begin{array}{c}3.920 * * * \\
(1.329)\end{array}$ \\
\hline Crisis*Dividend & & $\begin{array}{l}-1.097 \\
(1.094)\end{array}$ & & & $\begin{array}{c}-0.595 \\
(0.978)\end{array}$ \\
\hline Crisis & & $\begin{array}{c}-0.912 * \\
(0.533)\end{array}$ & & & $\begin{array}{c}-0.758 \\
(0.484)\end{array}$ \\
\hline Toprate*Dividend & & & $\begin{array}{c}0.373 * * * \\
(0.101)\end{array}$ & & $\begin{array}{c}0.385^{* * * *} \\
(0.104)\end{array}$ \\
\hline Toprate & & & $\begin{array}{c}0.0949 \\
(0.0720)\end{array}$ & & $\begin{array}{c}0.0901 \\
(0.0734)\end{array}$ \\
\hline Corprate*Dividend & & & & $\begin{array}{c}-0.00866 \\
(0.156)\end{array}$ & $\begin{array}{c}-0.172 \\
(0.136)\end{array}$ \\
\hline Constant & $\begin{array}{c}25.42 * * * \\
(1.235)\end{array}$ & $\begin{array}{c}25.53 * * * \\
(1.219)\end{array}$ & $\begin{array}{c}14.08 * * * \\
(2.403)\end{array}$ & $\begin{array}{c}25.55 * * * \\
(2.549)\end{array}$ & $\begin{array}{c}16.60 * * * \\
(2.698)\end{array}$ \\
\hline Observations & 1,188 & 1,188 & 1,188 & 1,188 & 1,188 \\
\hline R-squared & 0.091 & 0.103 & 0.244 & 0.091 & 0.255 \\
\hline Number of Clusters & 66 & 66 & 66 & 66 & 66 \\
\hline Country FE & Yes & Yes & Yes & Yes & Yes \\
\hline
\end{tabular}

Standard errors in parentheses

*** $\mathrm{p}<0.01,{ }^{* *} \mathrm{p}<0.05, * \mathrm{p}<0.1$

\footnotetext{
${ }^{1}$ There is some concern that model 5 is subject to multicollinearity. The top rate and corporate rate interaction terms are highly correlated. To account for this, models 3 and 4 only include the corporate or top rate interaction terms. Results are robust across the different models.
} 
Table A.1.1: Differences in differences to reference year 2009 (with Finland and Norway) ${ }^{2}$

\begin{tabular}{|c|c|c|c|c|c|}
\hline VARIABLES & $\begin{array}{c}(1) \\
\text { Model } 1 \\
\end{array}$ & $\begin{array}{c}(2) \\
\text { Model } 2 \\
\end{array}$ & $\begin{array}{c}(3) \\
\text { Model } 3 \\
\end{array}$ & $\begin{array}{c}(4) \\
\text { Model } 4 \\
\end{array}$ & $\begin{array}{c}(5) \\
\text { Model } 5 \\
\end{array}$ \\
\hline Treat & $\begin{array}{c}-3.861^{* * *} \\
(0.512)\end{array}$ & $\begin{array}{c}-3.722^{* * *} \\
(0.515)\end{array}$ & $\begin{array}{c}-3.842^{* * *} \\
(0.558)\end{array}$ & $\begin{array}{c}-3.861^{* * *} \\
(0.515)\end{array}$ & $\begin{array}{c}-3.725 * * * \\
(0.521)\end{array}$ \\
\hline Treat*Dividend (DID) & $\begin{array}{c}5.352 * * * \\
(1.431)\end{array}$ & $\begin{array}{c}5.562 * * * \\
(1.421)\end{array}$ & $\begin{array}{c}5.419 * * * \\
(1.364)\end{array}$ & $\begin{array}{c}5.274 * * * \\
(1.525)\end{array}$ & $\begin{array}{c}4.948 * * * \\
(1.541)\end{array}$ \\
\hline Crisis*Dividend & & $\begin{array}{l}-1.408 \\
(1.059)\end{array}$ & & & $\begin{array}{l}-1.028 \\
(1.088)\end{array}$ \\
\hline Crisis & & $\begin{array}{l}-0.932 * \\
(0.536)\end{array}$ & & & $\begin{array}{c}-0.792 \\
(0.515)\end{array}$ \\
\hline Toprate*Dividend & & & $\begin{array}{c}0.317 * * * \\
(0.113)\end{array}$ & & $\begin{array}{c}0.326 * * * \\
(0.119)\end{array}$ \\
\hline Toprate & & & $\begin{array}{c}0.0908 \\
(0.0696)\end{array}$ & & $\begin{array}{c}0.0861 \\
(0.0682)\end{array}$ \\
\hline Corprate*Dividend & & & & $\begin{array}{c}-0.0203 \\
(0.170)\end{array}$ & $\begin{array}{l}-0.162 \\
(0.159)\end{array}$ \\
\hline Constant & $\begin{array}{c}25.03^{* * *} \\
(1.249)\end{array}$ & $\begin{array}{c}25.15^{* * * *} \\
(1.253)\end{array}$ & $\begin{array}{c}14.87 * * * \\
(2.501)\end{array}$ & $\begin{array}{c}25.33^{* * * *} \\
(2.787)\end{array}$ & $\begin{array}{c}17.33^{* * *} \\
(2.589)\end{array}$ \\
\hline Observations & 1,260 & 1,260 & 1,260 & 1,260 & 1,260 \\
\hline R-squared & 0.088 & 0.101 & 0.187 & 0.088 & 0.199 \\
\hline Number of Clusters & 70 & 70 & 70 & 70 & 70 \\
\hline Country FE & Yes & Yes & Yes & Yes & Yes \\
\hline
\end{tabular}

Standard errors in parentheses

*** $\mathrm{p}<0.01,{ }^{* *} \mathrm{p}<0.05,{ }^{*} \mathrm{p}<0.1$

2 There is some concern that model 5 is subject to multicollinearity. The top rate and corporate rate interaction terms are highly correlated. To account for this, models 3 and 4 only include the corporate or top rate interaction terms. Results are robust across the different models. 
Table A.2: Differences in differences (ref. year 2009) with leads and lags (without Finland and Norway)

\begin{tabular}{lcc|cc}
\hline VARIABLES & $\begin{array}{c}\text { Without Controls } \\
\text { Coefficient }\end{array}$ & $(\mathrm{SE})$ & $\begin{array}{c}\text { With Controls } \\
\text { Coefficient }\end{array}$ & $(\mathrm{SE})$ \\
\hline DID2000 & -1.469 & $(2.072)$ & 0.0259 & $(2.723)$ \\
DID2001 & -1.617 & $(1.771)$ & -0.225 & $(2.443)$ \\
DID2002 & -1.067 & $(1.708)$ & 0.0912 & $(2.328)$ \\
DID2003 & -1.705 & $(1.506)$ & -0.481 & $(2.186)$ \\
DID2004 & $-2.317 * *$ & $(1.056)$ & -1.093 & $(1.488)$ \\
DID2005 & -1.212 & $(1.021)$ & -0.142 & $(1.345)$ \\
DID2006 & -1.316 & $(0.863)$ & -0.290 & $(1.247)$ \\
DID2007 & -0.952 & $(0.836)$ & -0.0486 & $(1.144)$ \\
DID2008 & -0.117 & $(0.487)$ & -0.0473 & $(0.501)$ \\
DID2009 & 0 & $(0)$ & 0 & $(0)$ \\
DID2010 & $1.896^{* *}$ & $(0.775)$ & $1.618^{* *}$ & $(0.673)$ \\
DID2011 & $1.680^{*}$ & $(0.898)$ & 1.286 & $(0.860)$ \\
DID2012 & $3.094^{* * *}$ & $(1.013)$ & $2.659^{* * *}$ & $(0.935)$ \\
DID2013 & $3.183^{* * *}$ & $(1.015)$ & $2.565^{* *}$ & $(1.261)$ \\
DID2014 & $4.026^{* * *}$ & $(1.115)$ & $3.416^{* *}$ & $(1.509)$ \\
DID2015 & $4.354^{* * *}$ & $(1.162)$ & $3.508^{* *}$ & $(1.511)$ \\
DID2016 & $5.105^{* * *}$ & $(1.274)$ & $3.714^{* *}$ & $(1.699)$ \\
DID2017 & $5.363^{* * *}$ & $(1.430)$ & $4.528^{* * *}$ & $(1.655)$ \\
Constant & $22.38^{* * *}$ & $(1.106)$ & $18.25^{* * *}$ & $(2.749)$ \\
Observations & & & & \\
R-squared & 1,188 & & 1,188 & \\
Number of Clusters & 0.220 & & 0.352 & \\
Country FE & 66 & & Yes & \\
\hline
\end{tabular}

Standard errors in parentheses

$* * * \mathrm{p}<0.01,{ }^{* *} \mathrm{p}<0.05,{ }^{*} \mathrm{p}<0.1$ 
Table A.2.1: Differences in differences (ref. year 2009) with leads and lags (with Finland and Norway)

\begin{tabular}{|c|c|c|c|c|}
\hline \multirow[b]{2}{*}{ VARIABLES } & \multicolumn{2}{|c|}{ Without Controls } & \multirow[t]{2}{*}{ With Controls } & \multirow[b]{2}{*}{ SE } \\
\hline & Coefficients & SE & & \\
\hline DID2000 & -2.830 & $(2.235)$ & -2.743 & $(3.341)$ \\
\hline DID2001 & -2.655 & (1.831) & -2.581 & (2.958) \\
\hline DID2002 & -2.451 & (1.875) & -2.480 & $(2.942)$ \\
\hline DID2003 & $-3.053 *$ & (1.715) & -2.975 & $(2.750)$ \\
\hline DID2004 & $-3.630 * * *$ & (1.384) & -3.475 & $(2.232)$ \\
\hline DID2005 & -2.047 & (1.274) & -1.927 & (1.959) \\
\hline DID2006 & -1.241 & $(0.830)$ & -1.073 & (1.315) \\
\hline DID2007 & -0.898 & $(0.796)$ & -0.735 & (1.194) \\
\hline DID2008 & -0.110 & (0.439) & -0.0801 & $(0.478)$ \\
\hline DID2009 & 0 & $(0)$ & 0 & $(0)$ \\
\hline DID2010 & $1.788 * *$ & $(0.783)$ & $1.564^{* *}$ & $(0.628)$ \\
\hline DID2011 & $1.584^{*}$ & (0.858) & 1.136 & $(0.838)$ \\
\hline DID2012 & $3.040 * * *$ & (0.979) & $2.528 * * *$ & $(0.919)$ \\
\hline DID2013 & $3.124 * * *$ & (0.959) & $2.069 *$ & (1.225) \\
\hline DID2014 & $4.184^{* * *}$ & (1.084) & $3.102 * *$ & (1.467) \\
\hline DID2015 & $4.518 * * *$ & (1.125) & $3.255 * *$ & (1.471) \\
\hline DID2016 & $5.357 * * *$ & (1.251) & $3.645^{* *}$ & (1.615) \\
\hline DID2017 & $5.658 * * *$ & (1.423) & $4.421 * * *$ & (1.582) \\
\hline Constant & $22.56 * * *$ & (1.087) & $18.35^{* * *}$ & (3.102) \\
\hline Observations & 1,260 & & 1,260 & \\
\hline R-squared & 0.181 & & 0.264 & \\
\hline Number of Clusters & 70 & & 70 & \\
\hline Country FE & Yes & & Yes & \\
\hline
\end{tabular}


Table A.3: Coefficients of Interaction Dummy in Linear Regressions (with Finland and Norway)

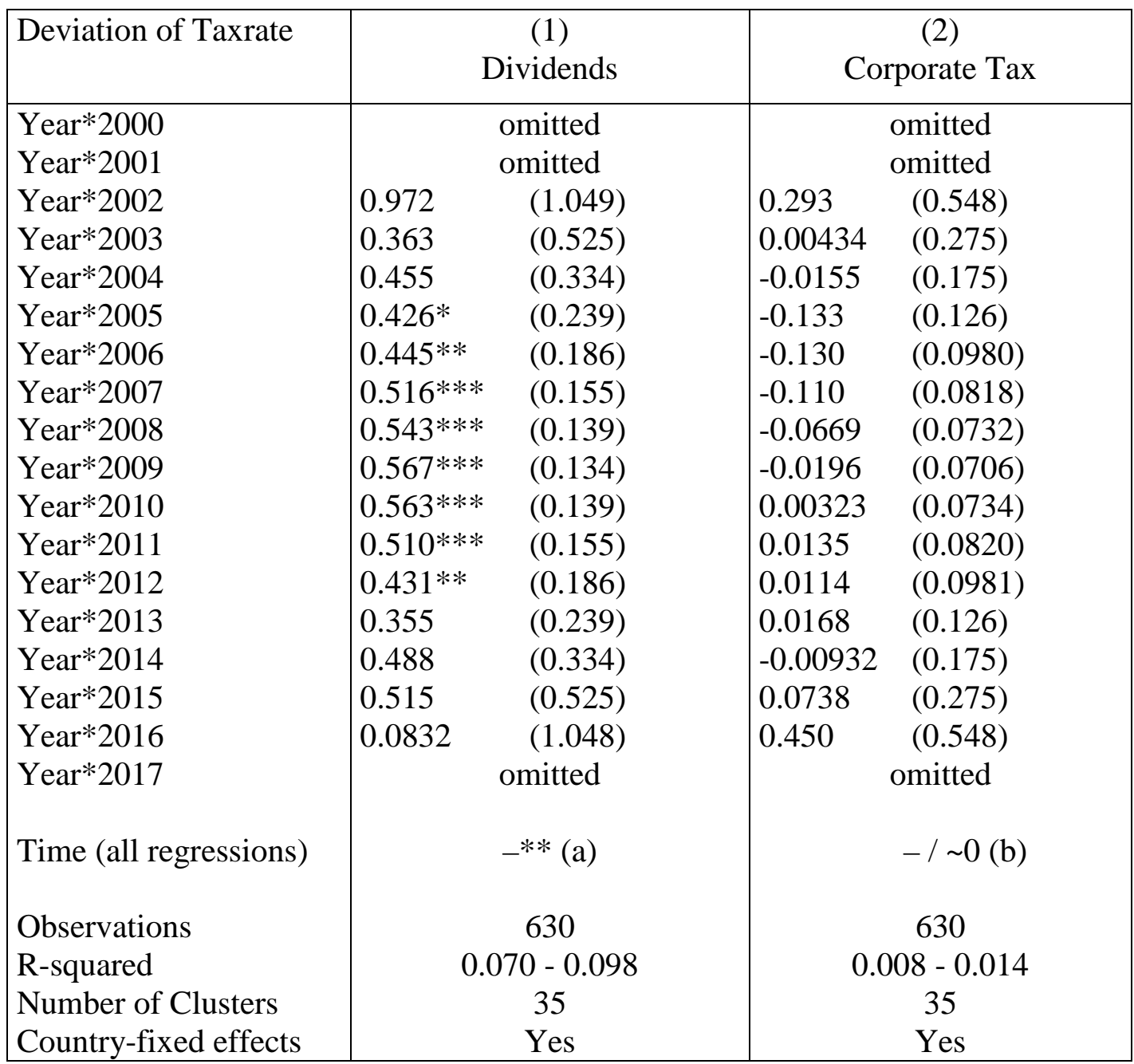

Standard errors in parentheses. ${ }^{\star \star \star} p<0.01,{ }^{\star \star} p<0.05,{ }^{\star} p<0.1$

All regressions include a constant.

(a) The coefficient varies between -0.57 and -0.19 in all regressions, increasing towards the later year regressions. It is -1.15 in that with the 2002 year dummy; it is significant in all but those regressions with year dummies before 2007.

(b) The coefficient varies mostly between -0.078 and 0.09 in all regressions, except for the regression with the year dummy 2002 , in which it is -0.34 ; it is insignificant in all regressions. 
Table A.3.1: Coefficients of Interaction Dummy in Linear Regressions (without Finland and Norway)

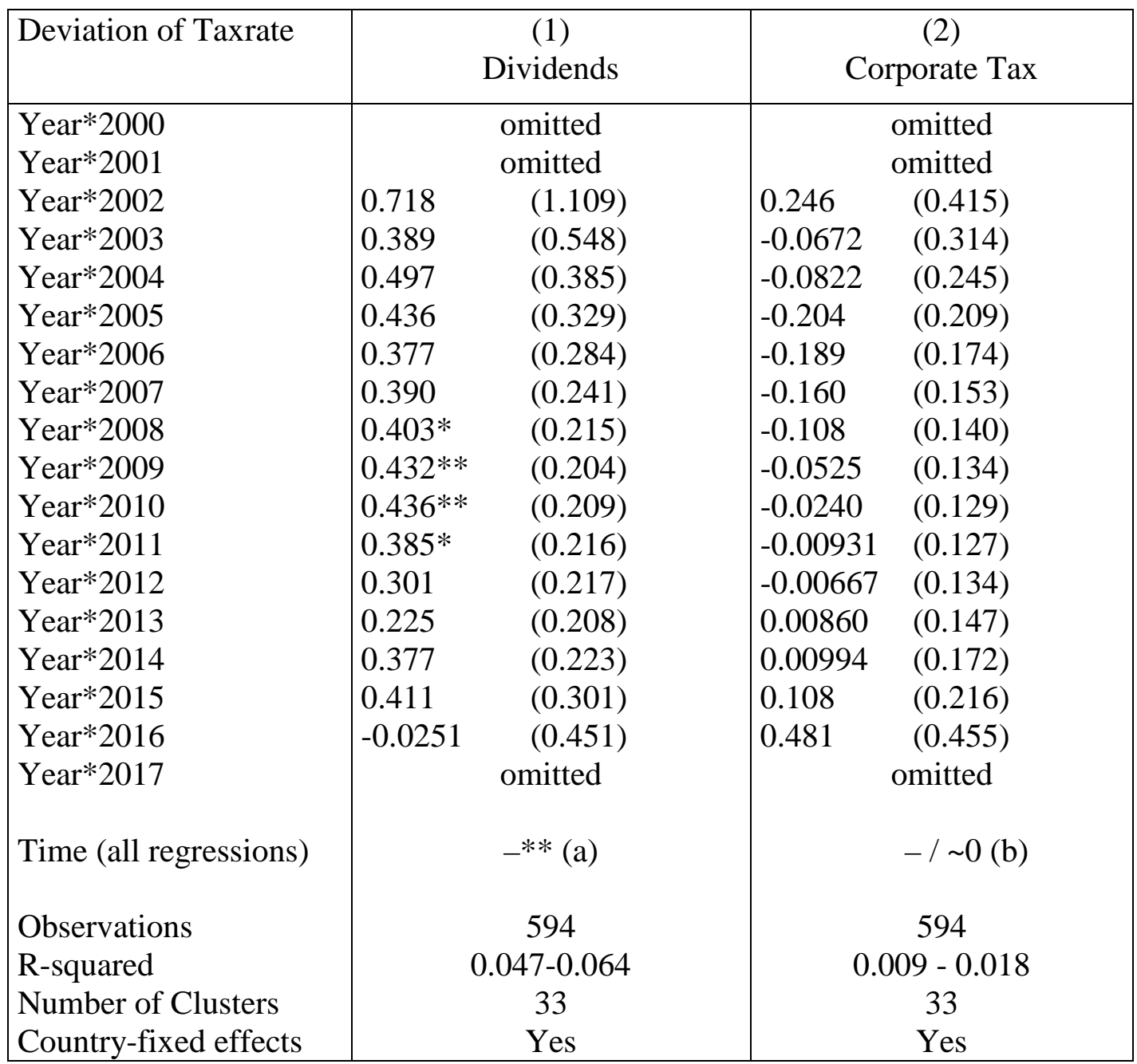

Standard errors in parentheses. ${ }^{\star \star \star} p<0.01,{ }^{\star \star} p<0.05,{ }^{\star} p<0.1$

All regressions include a constant.

(a) The coefficient varies between -0.84 and -0.19 in all regressions, increasing towards the later year regressions. It is insignificant in regressions with year dummies before 2008 and significant from then on.

(b) The coefficient varies mostly between -0.046 and 0.13 in all regressions, except for the regression with the year dummy 2002, in which it is -0.3 ; it is insignificant in all regressions. 


\begin{tabular}{lcc}
\hline & $(1)$ & $(2)$ \\
VARIABLES & Dividends & Corporate Profits \\
\hline Year & $-0.226^{* *}$ & -0.0379 \\
& $(0.0942)$ & $(0.0507)$ \\
Constant & $464.1^{* *}$ & 81.47 \\
& $(189.2)$ & $(101.7)$ \\
Observations & 630 & 630 \\
R-squared & 0.070 & 0.008 \\
Number of Clusters & 35 & 35 \\
Country FE & Yes & Yes \\
\multicolumn{2}{l}{ Robust standard errors in parentheses } \\
& $* * * \mathrm{p}<0.01, * * \mathrm{p}<0.05, * \mathrm{p}<0.1$ &
\end{tabular}

\section{Why the Fall in the Variation of Portfolio Capital Tax Rates Lags Behind}

In this appendix we explain why the variation of dividend tax rates across countries did not develop in parallel to the variation of corporate tax rates that, all else equal, theories of diffusion and tax competition would expect to find. As can be seen in Figure 4 of the main text, dividend tax rate variation was higher at the beginning of our observation period (2000) and exhibited a steeper downward trend than corporate tax rate variation. As we shall argue in the following, the reason for the different levels of variation in 2000 and the lack of parallel development can be explained by the fact that dividend taxation sits at the interface of corporate and personal taxation. In particular, we argue that its link to personal income taxation and the attempt of policymakers in some countries to cling to the notion of synthetic income taxation throughout the 1990s had caused a delay in the downward trend of the variation (but not the average) of dividend tax rates. In order to make this point, we discuss the mechanics of income tax systems 
and go back in time to consider the development of dividend, corporate and top income tax rates since 1981 .

In designing their income tax systems policymakers have to make two decisions concerning the interrelation between (1) corporate and personal capital income tax and (2) personal capital income and labor income tax. With respect to the first issue they have to decide whether the shareholder receives tax relief for the corporate tax paid by the corporation. With respect to the second issue, they have to decide whether labor and capital income are taxed at the same rate (synthetic taxation) or differentiated rates (dual income tax). While choices varied across countries and time, we can roughly distinguish three periods. ${ }^{3}$

\section{Before 1986}

Until the mid-1980s many OECD countries operated the classical system of corporate and dividend taxation. Corporations were considered as separate from their shareholders. Consequently, they paid corporate profit taxes and the shareholder paid income tax on the distributed earnings without any tax relief for the tax paid by the corporation. In many countries the taxation of capital income was integrated into the general personal income tax schedule (synthetic taxation). The stated ideal behind synthetic taxation is that income from all sources (labor and capital) is to be taxed equally. In Figure A.1 (depicting the average tax rates between 1981 and 2017) and Figure A.3 (showing the difference of the dividend and corporate rate to the top income rate respectively) we can thus see that the net dividend tax at shareholder level and the top statutory income tax were closely aligned. Likewise, the variation across countries is similar

\footnotetext{
${ }^{3}$ The data source for all Figures is the same as in the main article, i.e. OECD 2018; ibid.; ibid.. In addition, we also use the "historical tables" from 1981 to 1999 that the OECD also provides on their website. The OECD warns that the historical tables are not in all respects fully comparable with the current series from 2000 onwards. For details see ibid.. As can be seen in Figures A.1 to A.3 this does not seem to be a problem with respect to corporate and dividend taxes, but the top income rate time series exhibits a significant jump between 1999 and 2000. To indicate that these are not identical data, the observations between 1999 and 2000 are not connected.
} 
to the variation of personal income tax rates and higher than in corporate rates (see Figure A.2 depicting the deviation from the mean).

\section{6 to 1999}

This begins to change with the wave of 'market-conforming' tax reforms since the mid-1980s. The dashed line in all Figures mark the US Tax Reform Act 1986 because it is considered the main starting point of the tax competition era (though the UK's 1984 reform was also significant). Both corporate and personal income tax rates were lowered. ${ }^{4}$ At about the same time, the majority of OECD countries began to move away from the classical system of shareholder taxation to an imputation system, i.e. a system where the shareholder can claim a tax credit for the profit tax paid at the corporation level. ${ }^{5}$ It can be argued that such a system is more marketconforming as it eliminates the "double taxation" of capital income and ensures that there is no distortion in the allocation of funds between the incorporated and unincorporated business sectors. ${ }^{6}$ The company is not viewed as separate from the shareholder anymore and corporations' costs of raising capital decrease as the tax burden on their investors (shareholders) is lowered. In other words, the move entails a decrease in the tax burden on capital. Nevertheless, in terms of the relationship between the taxation of capital and labor income the stated ideal behind such a system is still synthetic taxation. Whereas under the classical system the taxation of personal capital income and labor income were aligned, the alignment is now to be achieved between labor income taxes and overall capital income taxes, i.e. the sum of corporate and personal capital tax rates. ${ }^{7}$ This is desirable for efficiency reasons, because it ensures uniform taxation

\footnotetext{
${ }^{4}$ The downward trend of these two tax rates is not independent from each other. One reason for lowering the personal income tax is the downward trend of corporate tax rates that drags down personal rates via the backstop function of the corporate rate.

${ }^{5}$ Kari and Ylä-Liedenpohja 2002, 2; OECD 1991.

${ }^{6}$ King 1977; Mintz 1995.

7 International Monetary Fund (IMF) 2014,38-39.
} 
of all income and thus is less distortionary. In terms of equity it is meant to ensure equal tax treatment of labor and capital income, irrespective of whether it is collected at the corporate or personal level. ${ }^{8}$

Beginning in the early 1990s some countries intentionally gave up on synthetic taxation. Most prominently the Nordic countries, Sweden, Norway and Finland (Denmark had already introduced it earlier) switched to dual income taxation. Whereas capital income, which is considered to be sensitive income because of its mobility, is taxed at low and uniform rates, labor income, which is less mobile, is taxed at progressively increasing and higher rates. These developments in the late 1980s and 1990s are driven by the necessities of tax competition. ${ }^{9}$ Imputation systems imply lower tax burdens for investors, and the introduction of dual tax systems, which is combined with imputation in the Nordic countries, implies an even further rate reduction. The parallel move towards lower personal income tax rates, including the tax rates on dividend income, and the change from classical to imputation systems, and then a little later also dual income tax systems, in some countries explains why net dividend tax rates at the shareholder level (our indicator) decline sharply since the mid-1980s and are lower than corporate tax rates from the late 1980s onwards (see Figure A.1).

More importantly for our purposes, these developments can explain why the variation of dividend tax rates across countries increased after 1986 and remained high throughout the 1990s (see Figure A.2). As the introduction of imputation systems was spread over a long time period, a few countries actually changed back and forth between the two systems ${ }^{10}$ and some stayed with the classical system, e.g. the USA, the variation increased. Likewise, introduction of the dual income tax only occurred in some countries in our sample. We can broadly distinguish

\footnotetext{
${ }^{8}$ There is in fact an almost philosophical debate on whether corporations can be seen as (legal) personalities distinct from their shareholders or not, see e.g. Avi-Yonah 2004.

${ }^{9}$ Cnossen 1999; Ganghof 2006, $77 \mathrm{ff}$. .

${ }^{10}$ Cf. OECD 1991.
} 
three groups with changing group membership across time: countries with synthetic and classical systems tend to have a high dividend tax rate; countries with synthetic and imputation systems have a medium tax rate; and countries with dual tax systems and imputation systems have low dividend tax rates. The last group, however, experimented with either including dividends in the personal income tax schedule or excluding them, as the cases of Finland and Norway (discussed in the article) exemplify. All in all, these differences in the tax systems across countries can plausibly explain the high level of variation in dividend tax rates throughout the 1990s. In contrast, corporate rate variation remained at a low and slowly decreasing level during this period (Figure A.2).

\section{Since 2000}

In the third period, starting in 2000, a number of OECD countries reverted back to classical systems but in a strongly modified version. ${ }^{11}$ Among them, Germany, Finland, France, Italy and Norway eliminated their imputation systems between 1999 and 2006 due to legislation by the European Court of Justice. The Court argued that imputation systems only providing credits to domestic shareholders discriminated against foreign shareholders and violated the single market principle. ${ }^{12}$ In moving to the modified classical system most countries gave up on synthetic taxation. Dividend income is no longer taxed within the personal income tax schedule but at a lower rate - or formally at the same rate but with many exemptions and deductions that effectively lead to a lower rate at the net shareholder level. ${ }^{13}$ This relatively broad trend towards

\footnotetext{
${ }^{11}$ Ainsworth 2016; Amiram, Bauer, and Frank 2017.

${ }^{12}$ Amiram, Bauer, and Frank 2017; Graetz and Warren 2016. The decision has been discussed quite controversially in the literature. For example, it may be questioned why governments should grant tax credits to investors that are not liable to tax in their country in the first place. Ibid., $679 \mathrm{f}$. .

13 Owens 2012, 117. While the result is identical to a dual income tax, it is often not introduced in a coherent and principled way. On the trade-offs involved in making these policy choices, see Ganghof 2006, chapter 3 and 4.
} 
lower dividend tax rates ${ }^{14}$ and dual or semi-dual income taxation ${ }^{15}$ leads to increased uniformity across countries, the variation of dividend tax rates falls (Figure A.2).

This, finally, changes again in 2009 (Figures A.1 and A.2), which is of course the main topic of our paper.

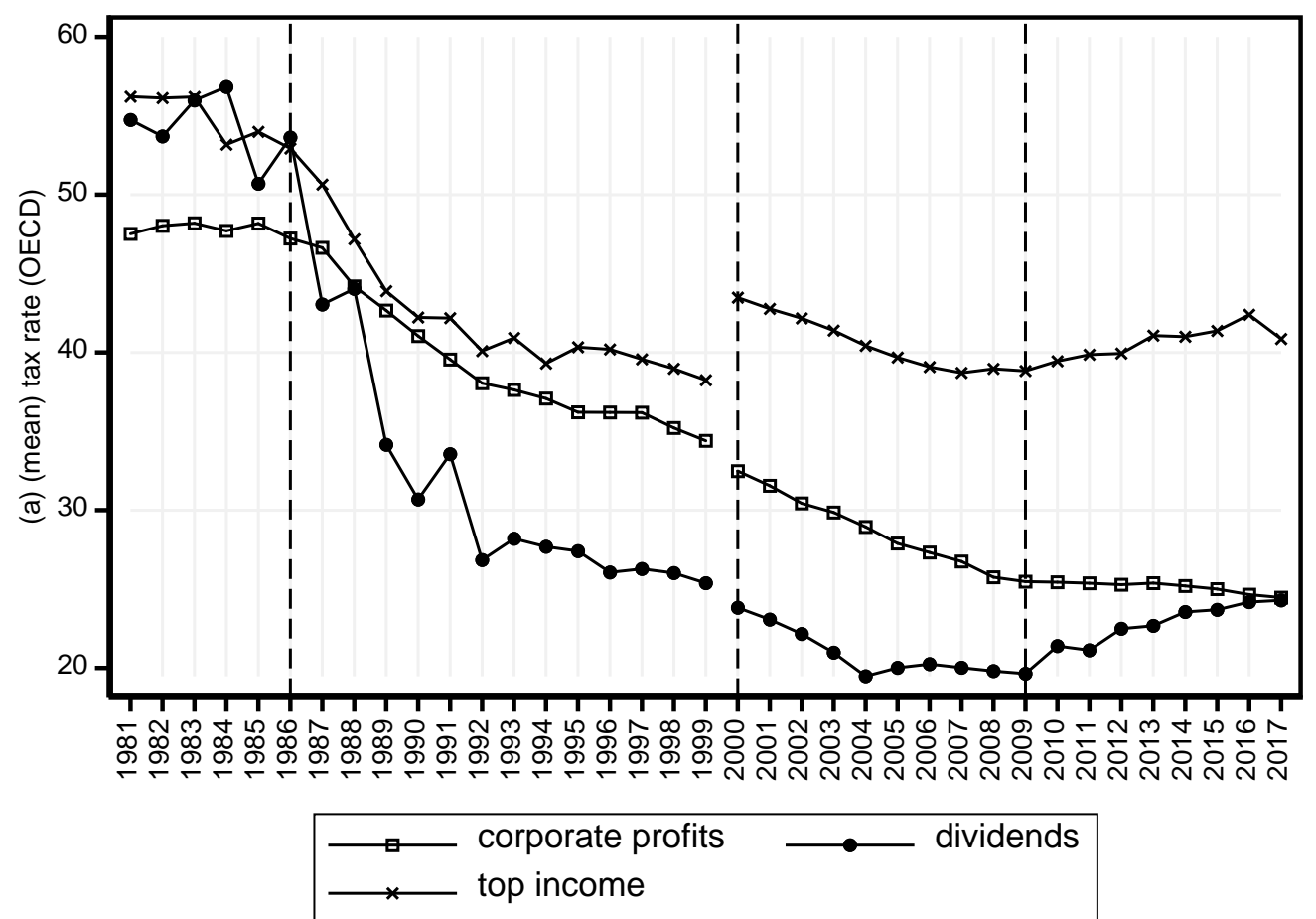

Figure A.1: (Mean) Tax Rates, OECD (1981-2017)

14 OECD 2006, 23.

${ }^{15}$ Brys et al. 2016, 39. 

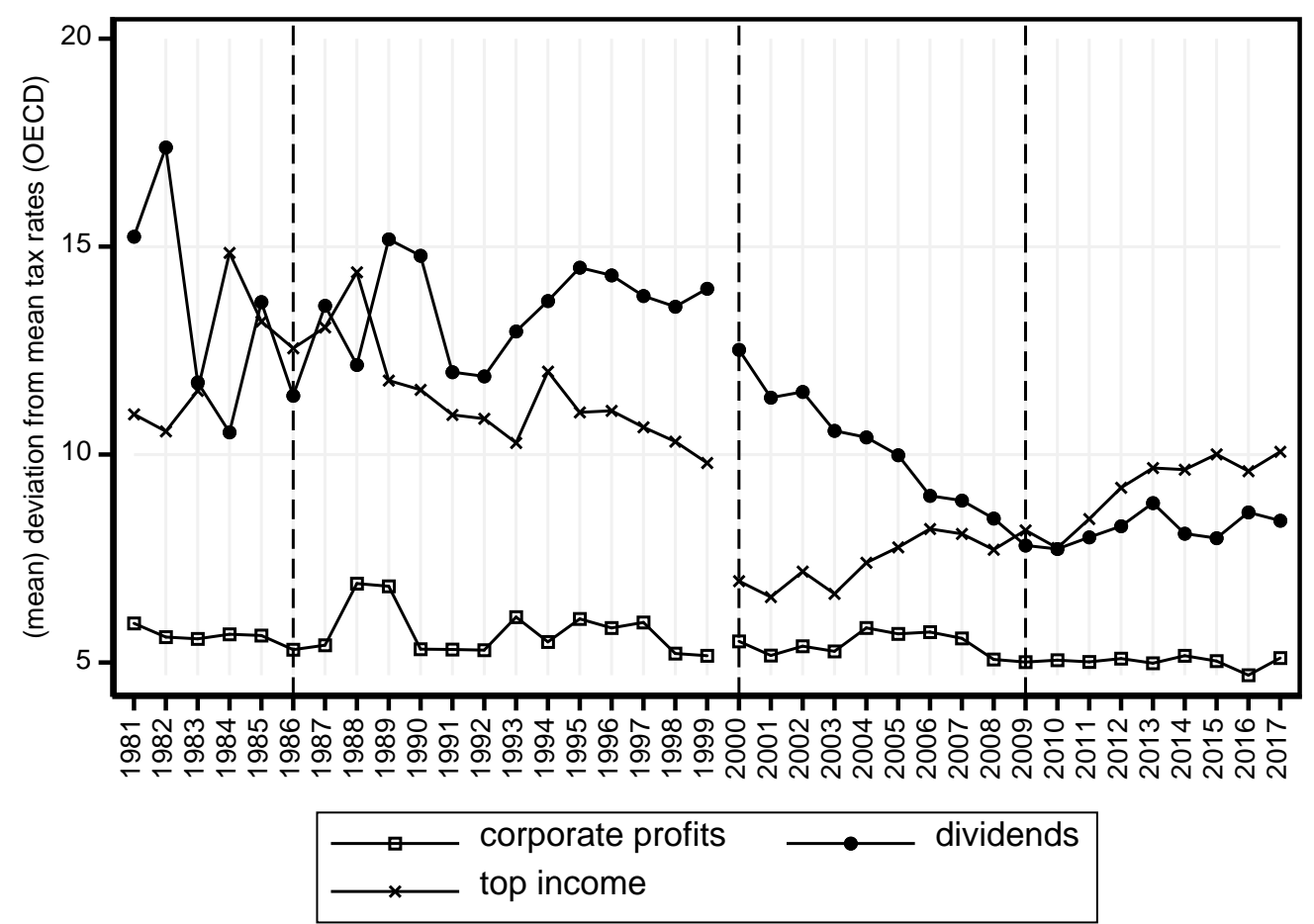

Figure A.2: (Mean) Deviation from Mean Tax Rates, OECD (1981-2017)

\section{Personal income taxation as a moderate conditioning factor of tax competition on dividend}

rates

This account shows that in dividend taxation it took until the early 2000s for the competitive pressures to develop their full impact. The reason for that is ultimately an institutional rigidity that results from the fact that dividend taxation is integrated into personal income taxation. Since labor income is less mobile it is not subject to tax competition to the same extent as capital income. At the same time there are strong fairness considerations operating at the domestic level that suggest the application of the principle of synthetic and progressive income taxation to all income alike. This means, you first have to decouple dividend taxes from personal income taxes before you can forcefully compete on dividend tax rates. Doing so is fraught with politically costly choices. Hence, national policy makers are torn between the need to react to com- 
petitive pressures but are constrained in their maneuvering room. As a consequence, policymakers experiment with different ways of adapting to tax competition and this occurs at a slower pace and in an uneven way. Dividend rate variation temporarily increases. ${ }^{16}$

However, the development sketched above shows that over time the pressures of tax competition overcame the institutional rigidity and the personal income tax loses its conditioning impact on dividend taxation. The fact that the gap between dividend rates and top personal income rates steadily increases, whereas that between the corporate and dividend rate becomes smaller after the year 2000 is suggestive of this (Figure A.3). The corporate tax rate becomes the "linchpin” of capital income taxation. ${ }^{17}$

${ }^{16}$ While there are related constraints on corporate taxation - it is advisable to align the corporate and personal income tax rate to foreclose tax arbitration possibilities Ganghof 2006 - they are less pronounced, hence the decrease in variation is more steady and there is far less variation at the beginning of the 2000s.

${ }^{17}$ Cnossen 1999: 25. 


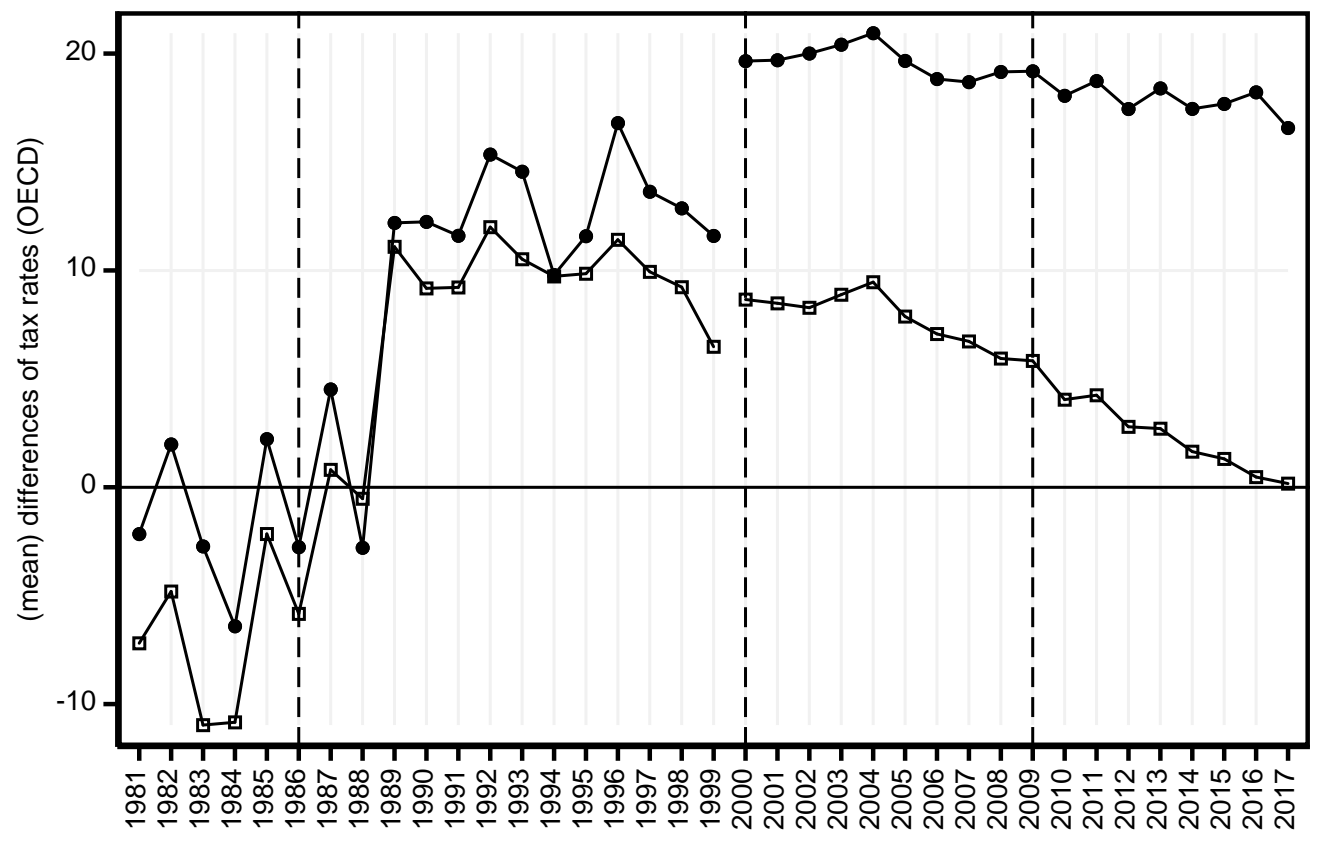

$\longrightarrow \Delta$ corporate-dividend rate $\longrightarrow-\Delta$ top-dividend rate

Figure A.3: Difference of Dividend to Top and Corporate Rates, OECD

(1981-2017)

\section{References}

Ainsworth, Andrew. 2016. Dividend Imputation: The International Experience. JASSA - The Finsia Journal of Applied Finance(1): 58-63.

Amiram, Dan , Andrew M. Bauer, and Mary Margaret Frank. 2017. Tax Avoidance at Public Corporations Driven by Shareholder Taxes: Evidence from Changes in Dividend Tax Policy. In Darden Business School Working Paper No. 2111467. http://dx.doi.org/10.2139/ssrn.2111467.

Avi-Yonah, Reuven S. 2004. Corporations, Society, and the State: A Defense of the Corporate Tax. Virginia Law Review 90: 1193-254.

Brys, Bert, Sarah Perret, Alastair Thomas, and Pierce O’Reilly. 2016. Tax Design for Inclusive Economic Growth. In OECD Taxation Working Papers No. 26. Paris. http://dx.doi.org/10.1787/22235558.

Cnossen, Sijbren. 1999. Taxing Capital Income in the Nordic Countries: A Model for the European Union? FinanzArchiv 56(1): 18-50. 
Ganghof, Steffen. 2006. The Politics of Income Taxation. A Comparative Analysis of Advanced Industrial Countries. Colchester: ECPR Press.

Graetz, Michael J., and Alvin C. Warren. 2016. The Integration of Corporate and Shareholder Taxes. National Tax Journal 39(3), 341-348 69(3): 677-700.

International Monetary Fund (IMF). 2014. Fiscal Policy and Income Inequality. In IMF Policy Paper. 23 January 2014. https://www.imf.org/external/np/pp/eng/2014/012314.pdf (last accessed 26 January 2017).

Kari, Seppo, and Jouko Ylä-Liedenpohja. 2002. Classical Corporation Tax as a Global Means of Tax Harmonization. In CESifo Working Paper No. 665 (1).

King, M. 1977. Public Policy and the Corporation. London: Chapman and Hall.

Mintz, Jack. 1995. The Corporation Tax: A Survey. Fiscal Studies 16(4): 23-68.

OECD. 2006. Fundamental Reform of Personal Income Tax. Paris: OECD Publishing.

- 2018. Oecd Tax Database. http://www.oecd.org/tax/tax-policy/tax-database.htm (last accessed 25 December 2018).

_ 1991. Taxing Profits in a Global Economy. Domestic and International Issues. Paris: OECD.

Owens, Jeffrey. 2012. Global Trends in Tax Systems. Tax Notes International 68(1): 115-25. 